\title{
Vaccines for canine leishmaniasis
}

\section{Clarisa B. Palatnik-de-Sousa*}

Laboratório de Biologia e Bioquímica de Leishmania, Departamento de Microbiologia Geral, Instituto de Microbiologia Paulo de Góes, Universidade Federal do Rio de Janeiro, Rio de Janeiro, Brazil

\section{Edited by:}

Nathan Peters, National Institute of

Allergy and Infectious Diseases, USA

\section{Reviewed by:}

Nathalie Labrecque, University of

Montreal, Canada

Shaden Kamhawi, National Institutes

of Health, USA

\section{*Correspondence:}

Clarisa B. Palatnik-de-Sousa, Laboratório de Biologia e Bioquímica de Leishmania, Instituto de Microbiologia Paulo de Góes, Centro de Ciências da Saúde, Universidade Federal do Rio de Janeiro, Avda. Carlos Chagas 373, Caixa Postal 68040, CEP 21941-902 Cidade Universitária, Ilha do Fundão, Rio de Janeiro, Rio de Janeiro, Brazil. e-mail:immgcpa@micro.ufri.br
Leishmaniasis is the third most important vector-borne disease worldwide. Visceral leishmaniasis $(\mathrm{VL})$ is a severe and frequently lethal protozoan disease of increasing incidence and severity due to infected human and dog migration, new geographical distribution of the insect due to global warming, coinfection with immunosuppressive diseases, and poverty. The disease is an anthroponosis in India and Central Africa and a canid zoonosis (ZVL) in the Americas, the Middle East, Central Asia, China, and the Mediterranean. The ZVL epidemic has been controlled by one or more measures including the culling of infected dogs, treatment of human cases, and insecticidal treatment of homes and dogs. However, the use of vaccines is considered the most cost-effective control tool for human and canine disease. Since the severity of the disease is related to the generation of T-cell immunosuppression, effective vaccines should be capable of sustaining or enhancing the T-cell immunity. In this review we summarize the clinical and parasitological characteristics of ZVL with special focus on the cellular and humoral canine immune response and review state-of-the-art vaccine development against human and canine VL. Experimental vaccination against leishmaniasis has evolved from the practice of leishmanization with living parasites to vaccination with crude lysates, native parasite extracts to recombinant and DNA vaccination. Although more than 30 defined vaccines have been studied in laboratory models no human formulation has been licensed so far; however three second-generation canine vaccines have already been registered. As expected for a zoonotic disease, the recent preventive vaccination of dogs in Brazil has led to a reduction in the incidence of canine and human disease. The recent identification of several Leishmania proteins with T-cell epitopes anticipates development of a multiprotein vaccine that will be capable of protecting both humans and dogs against $\mathrm{VL}$.

Keywords: vaccines, canine leishmaniasis, visceral leishmaniasis, zoonotic visceral leishmaniasis

\section{WHY IS LEISHMANIOSIS IMPORTANT TO HUMAN AND VETERINARY MEDICINE?}

Human leishmaniasis, caused by several species of Leishmania, comprises a group of diseases which are mostly zoonotic. These include visceral leishmaniasis (VL) and the cutaneous and mucocutaneous forms (CL). This group of infections is the third most important vector-borne disease after malaria and lymphatic filariasis (Solano-Gallego et al., 2009).

According to WHO, leishmaniasis is considered to be endemic in 88 countries, with more than 350 million people at risk. The estimated incidence is 2 million new cases per year, 0.5 million of VL, and 1.5 million of CL [World Heath Organization (WHO, 2011)]. Without prompt appropriate treatment as many as $95 \%$ of kala-azar patients die resulting in at least 50,000 deaths per year worldwide (Chappuis et al., 2007). Ninety percent of the human cases of VL are notified in Bangladesh, India, Nepal, Sudan, and Brazil, $95 \%$ of the cases of human CL are reported in Bolivia, Brazil, and Peru (mucocutaneous leishmaniasis), and $90 \%$ of cutaneous leishmaniasis cases occur in Afghanistan, Brazil, Iran, Peru, Saudi Arabia, and Syria (WHO, 2011). These statistics and epidemiological data however, are certainly an underestimation since they were first published by WHO in 1993 and have remained unaltered until now (WHO, 2011). Over the last two decades however many factors determined the increase in the incidence of human VL. Among them we can consider the geographical spread of VL in Europe, Africa, America, and Asia (Romero and Boelaert, 2010; Palatnik-de-Sousa and Day, 2011) caused by human migration carrying infected dogs to areas where the specific insect vector was already present (Maguill, 1995); the expansion of the phlebotomine habitats due global warming (Witt et al., 2009); the increase in dog cases with a travel history (Duprey et al., 2006); the urbanization of the disease after deforestation (Harhay et al., 2011); and the frequent coinfection in HIV-positive individuals (Evans and Kedzierski, 2012).

Visceral leishmaniasis is a chronic and frequently lethal disease caused by protozoan parasites of the Leishmania donovani complex, order Kinetoplastida. The etiological agents are: $L$. donovani in India and Central Africa and Leishmania infantum in the Americas, the Middle East, Central Asia, China, and the Mediterranean. The human disease is lethal if not treated soon after the onset of clinicopathological abnormalities that include: malaise, anemia, cachexia, hypergammaglobulinemia, hepato-splenomegaly, and progressive suppression of the cellular immune response. The $L$. donovani complex species are intracellular parasites of 
macrophages of lymphoid organs such as the spleen, lymph nodes, bone marrow, and liver. Their biological cycle alternates between the amastigote form in the vertebrate host and the promastigote form in the gut of the sand-fly vector (WHO, 2011).

Considering the presence or absence of animal reservoirs for Leishmania, two basic types of epidemiological cycles are noted: zoonotic (ZVL) or anthroponotic (AVL; reviewed by Palatnik-de-Sousa and Day, 2011).

AVL in India and Central Africa is caused by L. donovani and involves a severe parasitism of the blood and skin and an anthropophilic vector, making man the reservoir of the disease. In contrast, ZVL with dogs as the reservoir hosts is usually associated with L. infantum and is found in the Americas, the Middle East, Central Asia, China, and the Mediterranean. Sandflies become infected mostly by feeding on the skin of canids and humans are the final host of the parasites.

"One Health" proposes the unification of medical and veterinary sciences with the establishment of collaborative ventures in clinical care, surveillance and control of cross-species disease, education, and research into disease pathogenesis, diagnosis, therapy, and vaccination. The concept encompasses the human population, domestic animals and wildlife, and the impact that environmental changes ("environmental health") such as global warming will have on these populations. "One Health" proposes taking a holistic view of the previously distinct disciplines of human medicine, veterinary medicine, environmental science, and wildlife conservation (Palatnik-de-Sousa and Day, 2011). ZVL is a disease that epitomizes perfectly the need for a One Health approach since the disease occurs in both, dogs and humans, with similar symptoms, clinical outcome, and commitment of the integrity of the T-cell related immunity (Reis et al., 2010; Palatnik-de-Sousa and Day, 2011). Tools for control of canine ZVL will have impact on the reduction of the human incidence of ZVL (Palatnik-de-Sousa et al., 2009).

The present review examines the current state-of-the-art of the development and use of vaccines for canine leishmaniasis as the most worthy cost-benefit tool for the control and prevention of ZVL.

\section{LEISHMANIASIS IN CANIDS}

A broad range of immune responses and clinical manifestations have been described in canine ZVL (Baneth et al., 2008; SolanoGallego et al., 2011). These aspects have been thoroughly revised by the LeishVet group in order to establish guidelines for canine ZVL management (Solano-Gallego et al., 2011). Infection in dogs may be subclinical or manifested as a self-limiting disease, or a severe, and sometimes, even if treated, fatal illness (Solano-Gallego et al., 2011). Subclinical infection is not necessarily permanent and factors such as immunosuppression or concomitant diseases could break the equilibrium and lead to the progression of the clinical disease in dogs (Baneth et al., 2008; Solano-Gallego et al., 2009) as has been observed in humans coinfected with the human immunodeficiency virus and Leishmania (Alvar et al., 2008). Of note, the infection of cats by $L$. infantum was recently reported (Maia and Campino, 2011; Vides et al., 2011) and a correlation between cat infection by the feline immunodeficiency virus (FIV) and leishmaniasis was also described (Vides et al., 2011).
Since the proportion of clinical cases of canine ZVL is lower than that of the subclinical cases, and a positive correlation between clinical status and infectiosity to the sand-fly has been established (Travi et al., 2001), when high vector sand-fly and canine-host densities are present, the infection spreads quickly and extensively among the dog population (Quinnell et al., 1997, 2003; Oliva et al., 2006).

Several predisposing factors for the development of the disease have been described including breed, age, and genetic background. As for breed susceptibility, the German shepherd dog (Ranque et al., 1977; Abranches et al., 1991) together with the boxer (Ranque et al., 1977) and doberman (Abranches et al., 1991; Sideris et al., 1996) breeds appear to be predisposed to infection in France, Portugal, and Greece. In contrast, in Greece dogs of the collie breed are rarely infected (Sideris et al., 1996) and there is a well-known resistance in Ibizan hounds in Spain (Solano-Gallego et al., 2000). In Brazil however, the most affected breeds are the long-coated cocker spaniel (26.9\%) and the short-coated boxer (24.6\%; França-Silva et al., 2003), while in Italy no breed-related predisposition has been reported (Pozio et al., 1981).

Age seems to be an important factor (Pozio et al., 1981; Sideris et al., 1996). The distribution of the disease is considered bimodal in Europe, with the highest prevalence reported in dogs younger than 3 years and older than 8 years (Abranches et al., 1991; Cardoso et al., 2004). This was not supported however by a Brazilian study of 33,937 dogs (França-Silva et al., 2003). No specific canine gender predisposition has been described for ZVL in various endemic countries (Pozio et al., 1981; Abranches et al., 1991; Sideris et al., 1996; Antônio et al., 2007); however, in France a greater prevalence of ZVL was found among male dogs (Lanotte et al., 1975) and in an endemic area of Brazil high rates of seropositivity were also found among male animals (Mouta-Confort et al., 2010).

ZVL in dogs is a systemic disease that may potentially involve any organ, tissue, or body fluid and is manifested by non-specific clinical signs. The most common clinical manifestations and clinicopathological abnormalities found in canine ZVL are thoroughly described by the LeishVet group (Solano-Gallego et al., 2011). Skin lesions are the most frequent manifestation among them and may be seen along with other clinical signs or clinicopathological abnormalities. Clinical manifestations include generalized lymphadenopathy, loss of weight, altered appetite, lethargy, mucous membrane pallor, splenomegaly, polyuria and polydipsia, fever, vomiting and diarrhea, dermatitis, onychogryphosis, blepharitis, conjunctivitis, keratoconjunctivitis, uveitis, oral, genital, and/or nasal mucocutaneous and mucosal lesions, epistaxis, vascular, and neurological disorders (Solano-Gallego et al., 2011). Among the main laboratory abnormalities, hypergammaglobulinemia, hypoalbuminemia, decreased albumin/globulin ratio, anemia, leucopenia, thrombocytopenia, proteinuria, renal azotemia, and elevated liver enzyme activities were described (Solano-Gallego et al., 2011).

Renal disease may be the sole clinical manifestation of canine ZVL and it can progress from mild proteinuria to the nephrotic syndrome or to an end stage renal disease. Chronic renal failure is a severe result of disease progression and the main cause of mortality due to ZVL. However, the variable and non-specific clinical 
signs make the list of differential diagnoses wide and extensive (Solano-Gallego et al., 2011).

There have been numerous reports of the cutaneous pathology in the chronic stages of canine leishmaniosis and in some of these the presence of intracellular amastigotes within the macrophages forming the granulomatous dermatitis has been highlighted immunohistochemically (Koutinas et al., 1993; Maia and Campino, 2008; Day, 2011). Immunohistochemical studies have also shown that in the relatively milder clinical lesions of exfoliative dermatitis there is a low parasite burden, associated with enhanced expression of class II molecules of the major histocompatibility complex (MHC) by keratinocytes and a dermal T-cell infiltrate dominated by CD8 + cells over the CD4+ T helper (Th) subpopulation. In contrast, with the increasing severity of the cutaneous disease (the nodular form) there is reduced expression of class II molecules of the MHC by epidermal Langerhans cells and keratinocytes and fewer infiltrating T-lymphocytes (Papadogiannakis et al., 2005; Saridomichelakis, 2009). The lymph nodes of asymptomatic Leishmania-infected dogs are hyperplastic, but when the disease becomes symptomatic there is more often an atrophy of the lymph node cortex (Giunchetti et al., 2008a). The systemic pathological changes of canine ZVL have been reviewed recently (Day, 2011).

\section{CELLULAR IMIMUNE RESPONSES IN CANINE ZVL}

Susceptibility and resistance to the development of canine leishmaniasis depends on the immune response elicited in the dog after natural infection. According to Reis et al. (2010), the evaluation of different factors like parasite burden, humoral response, cellmediated immunity (CMI), or cytokine expression, have a predictive value for the progress of the infection and should, therefore, be taken into account as hallmarks of resistance and susceptibility to canine leishmaniasis (Reis et al., 2010). Increased levels of parameters like parasite load, IL-10, and TGF- $\beta$ expression, Leishmania-specific cell immunodepression or Leishmania-specific-IgG, IgM, IgA, and IgE serum antibodies are related to the clinical disease progression (Reis et al., 2010). By contrast, increased levels of parameters such as PBMCs proliferation after leishmanial antigen stimulation, IFN- $\gamma$ and TNF- $\alpha$ expression, proliferation of $\mathrm{CD} 4+, \mathrm{CD} 8+$, and B-cell subsets, or a positive leishmanin skin test (LST) are related to resistance (Reis et al., 2010). The different balance established between the factors involved in the host immune response are reflected in the spectrum of clinical forms that can be observed in naturally infected dogs, ranging from symptomatic severe canine leishmaniasis to asymptomatic animals (Reis et al., 2010). In agreement with that, the increase of IFN- $\gamma$ in cured cases was also described (Manna et al., 2008).

Other studies however, point out that the expression of IFN$\gamma$ was similar in symptomatic and asymptomatic dogs (Quinnell et al., 2001; Corrêa et al., 2007; Lage et al., 2007) or even higher and associated with the increase of parasite load and clinical status in susceptible dogs (Sanchez-Robert et al., 2008; Travi et al., 2009). Supporting these findings an initial asymptomatic phase, followed by a short-term production of Th1 type cytokines before the appearance of clinical signs (Santos-Gomes et al., 2002) or an initial elevation in IL- 4 followed by an increase in the Th1-associated IFN- $\gamma$ were described (Strauss-Ayali et al., 2007). Different from what Reis et al. (2010) stated, the high variability of the basal levels of these cytokines could not indicate the prognosis of the subsequent response against infection (Sanchez-Robert et al., 2008).

On the other hand, spleen cells from infected dogs showed a predominant expression of IL-10 that was positively correlated with parasitic load and clinical status severity (Pinelli et al., 1999; Chamizo et al., 2005; Lage et al., 2007; Alves et al., 2009).

A spectrum of innate and acquired immune responses to $L$. infantum infection is mounted by the canine-host (Baneth et al., 2008; Reis et al., 2010). Protective immunity to canine ZVL is Tcell-mediated and susceptibility to the overt disease is associated with a marked non-protective humoral immune response and a depressed CMI (Pinelli et al., 1994; Barbieri, 2006; Baneth et al., 2008).

When a cellular immune response is present, dogs appear asymptomatic and IDR (intradermal response to leishmanial antigen) positive, with higher levels of IL- 2 and TNF- $\alpha$ and a mixed $\mathrm{TH} 1 / \mathrm{TH} 2$ response involving $\mathrm{TH} 1$ evolution mediated primarily by IL-12, IL-18, and IFN-? (Chamizo et al., 2005). In asymptomatic dogs, macrophages are capable of killing amastigotes via the nitric oxide route (Vouldoukis et al., 1996), and there is an increase in CD8+ T-cells in peripheral lymphocytes, and MHC class II molecules and the receptors CD45RA and CD45RB are also expressed (Reis et al., 2006a). In contrast, symptomatic dogs show a failed cellular response, with no IDR or lymphocyte proliferation and the following additional characteristics: decrease in CD14+ monocytes; decrease in CD8+ (Reis et al., 2006a), CD4+ T-lymphocytes, and CD21+ B lymphocytes, either Leishmania-specific or not; antibody increase; deficiency of the costimulatory response; decrease of IFN- $\gamma$; and reduced expression of MHC class II molecules, which renders the animal more susceptible (Bourdoiseau et al., 1997; Moreno et al., 1999; Pinelli et al., 1999; Guarga et al., 2000, 2002; Borja-Cabrera et al., 2004).

The majority of infected dogs are likely to develop positive specific CMI expressed as proliferation of lymphocytes stimulated in vitro by Leishmania antigen or in vivo by a positive skin test early in infection. However, as the disease progresses in susceptible dogs, these responses diminish. Blood parasite load and Leishmania-specific CMI were shown to be inversely correlated during a longitudinal follow-up of experimentally infected dogs (Rodríguez-Cortés et al., 2007a). CMI unresponsiveness in progressive disease has been postulated to be due to the decrease in peripheral CD4+ T-cell numbers or the decreasing expression of co-stimulatory molecules such as B7 (Pinelli et al., 1999; Guarga et al., 2000; Alvar et al., 2004; Barbieri, 2006).

It is now widely accepted that protective immunity against Leishmania parasites is mediated by CD4+ T helper1 (Th1) cellular responses (Strauss-Ayali et al., 2007) and that the decrease in CD4+ T-cell numbers is highly correlated with parasitism and with the infectious condition to the sand-fly vector (Guarga et al., 2000, 2002; Travi et al., 2001). Similar to the situation in human VL patients, symptomatic disease in dogs is correlated with a "suppressive" pattern of T-cell responses, with a dominant role of IL-10 in ongoing, non-protective immune responses (Nylen and Sacks, 2007; Alves et al., 2009; Carrillo and Moreno, 2009). 


\section{HUMORAL IMMUNE RESPONSE IN CANINE ZVL}

Canine leishmaniosis is frequently associated with a marked humoral response, which is not protective and signifies failure to control the infection. The levels of Leishmania-specific immunoglobulins detected in symptomatic dogs are greater than those detected in infected but asymptomatic dogs, and a marked association was found between these levels, the clinical status, and the tissue parasite density (Reis et al., 2006b).

Canine ZVL shows very similar characteristics to the human disease (Palatnik-de-Sousa, 2008; Kaye and Aebischer, 2011). IgA, IgE, and IgM responses have been shown to be markers of the disease (Almeida et al., 2005; Iniesta et al., 2005; Rodríguez-Cortés et al., 2007b). An IgG antibody increase is also observed and correlated with symptomatology (Keenan et al., 1984; Courtenay et al., 2002; Nogueira et al., 2005) with the IgG1 subtype associated to susceptibility and severe disease and the IgG2 increased in natural resistant or vaccinated dogs (Deplazes et al., 1995; Bourdoiseau et al., 1997; Nieto et al., 1999; Solano-Gallego et al., 2001; Santana et al., 2002; Mendes et al., 2003; Quinnell et al., 2003; Ramiro et al., 2003; Borja-Cabrera et al., 2004; Fujiwara et al., 2005; Rafati et al., 2005; Santos et al., 2007). The IgG2 subtype also predominates in the canine response to vaccination against other infections (Ma et al., 1995; Chabalgoity et al., 2001). However, conflicting results have been reported, with the predominance of the IgG2 subtype observed in symptomatic dogs (Vercammen et al., 2002; Fernandez-Perez et al., 2003; Iniesta et al., 2005; Reis et al., 2006b; Day, 2007). Since all investigations used the same manufactured anti-dog conjugates, the discrepancy in results could be due to difference in titration of the conjugates (Mendes et al., 2003). On the other hand, while most studies defending the IgG2 predominance deal with vaccinated dogs and used purified (Mendes et al., 2003; Borja-Cabrera et al., 2004; Santos et al., 2007) or recombinant vaccine antigens for diagnosis (Nieto et al., 1999; Santana et al., 2002; Ramiro et al., 2003; Fujiwara et al., 2005; Rafati et al., 2005), the investigations that associate IgG2 to symptomatology, and disease used promastigote crude antigens (Vercammen et al., 2002; Fernandez-Perez et al., 2003; Rafati et al., 2005; Reis et al., 2006b). The differential affinity of the antigen could be another factor of the discrepancy. In dogs vaccinated with the $\mathrm{CPa}$ and $\mathrm{CPb}$ cysteine proteinases (Rafati et al., 2005) higher IgG2 than IgG1 titers were detected against the recombinant antigens but not against the $L$. infantum lysate. While the recombinant antigen interacts with a defined fraction of sera antibodies, the total lysate interacts with the whole plethora of antibodies directed against the total parasite (Palatnikde-Sousa, 2008). Another factor of discrepancy could be the use of different batches of the polyclonal anti-IgG2 and anti IgG1 antisera, which show low repeatability These difficulties stimulated Dr. M. J. Day to obtain dog monoclonal antibodies that recognize four different IgG subfractions (Day, 2007; Marcondes et al., 2011). Unfortunately, these antibodies are not commercially available.

\section{WHAT ARE THE SUITABLE ACTIONS FOR THE CONTROL OF CANINE ZVL}

For the control of leishmaniasis, WHO recommends: (1) the treatment of human patients, (2) the culling of seropositive infected dogs, and (3) the insecticidal treatment of human homes (Tesh, 1995; WHO, 2011).

Human cases should be diagnosed and treated as swiftly as possible (Ministério da Saúde, 2006). However in the case of ZVL humans are not the main reservoir of the infection.

A second preventive tool for ZVL in Brazil is control of the canine reservoir by removal and humane destruction of the Leishmania-seropositive and/or infected dogs and elimination of their carcasses (Ministério da Saúde, 2006). Although many studies support the efficacy of the culling control campaign (Magalhães et al., 1980; Ashford et al., 1993; Braga et al., 1998; Jerónimo et al., 2000; de Oliveira and de Araújo, 2003; Costa et al., 2007; Nunes et al., 2010) a few investigations show opposite results (Dietze et al., 1997; Paranhos-Silva et al., 1998; Moreira et al., 2004; De Souza et al., 2008; Nunes et al., 2010) and this strategy is frequently debated (Quinnell and Courtenay, 2009; Romero and Boelaert, 2010). At present, the removal of infected dogs is undertaken systematically only in Brazil (Palatnik-de-Sousa et al., 2001; Romero and Boelaert, 2010) and eventually in other South American countries (Romero and Boelaert, 2010) and China (Wang et al., 2010) and not regularly performed in the Mediterranean basin where chemotherapy treatment is preferred however they do not prevent relapses (Baneth and Shaw, 2002).

A third tool for control is the monitoring of the sand-fly vector in human residences and peri-domestically by spraying with pyrethroids. The use of deltamethrin-impregnated collars in dogs and of nets (with or without insecticides) in human homes and dog kennels is also recommended. A decrease in the prevalence of canine ZVL was observed after $65 \%$ permethrin spot-on treatment of dogs (Giffoni et al., 2002) and a significant reduction of anti-Leishmania antibody titers in dogs was observed in dogs using insecticide-impregnated collars (Killick-Kendrick et al., 1997; Maroli et al., 2001; Reithinger et al., 2004) and spot-on repellents (Miró et al., 2007; Ferroglio et al., 2008; Thomas et al., 2008). In southern Europe the use of deltamethrin-impregnated dog collars (Killick-Kendrick et al., 1997; Maroli et al., 2001) is preferred by many dog owners. Alternatively, there is substantial evidence for the efficacy of spot-on repellents containing imidacloprid, permethrin, pyriprole, metaflumizone, or amitraz (Miró et al., 2007; Ferroglio et al., 2008; Thomas et al., 2008). In the Mediterranean region, human and canine cases of ZVL are treated with antiparasitic drugs. In Europe, individual measures to protect dogs from sand-fly bites using insecticides are commonly practiced, but no public health surveillance and control interventions such as those applied in Brazil are in place (Palatnik-de-Sousa et al., 2001).

The mathematical model described by Dye condemned the epidemiological ZVL control campaign, considering it non-efficient and indeed, at low rates of canine seropositivity, no impact on the human incidence of the disease was observed (Dye, 1996; Palatnikde-Sousa et al., 2004). However, at higher rates of canine seropositivity, corresponding to more sensitive diagnostic methods, the number of infectious dogs declined interrupting the transmission and the spread of epidemics (Palatnik-de-Sousa et al., 2004). The low acceptance of culling of companion animals by their owners, the ethical dilemmas of veterinarians and humane reasons demand the development of alternative preventive tools. Mathematical modeling suggests that vector control and vaccination of 
dogs and/or humans would be more efficacious than dog culling (Dye, 1996).

\section{VACCINES FOR HUMAN LEISHMANIASIS}

In spite of an estimated 500,000 cases and more than 50,000 deaths annually (WHO, 2011), human VL has been considered an unattractive vaccine target for industry, being primarily a disease of the poor. Human VL however, ranks second only to malaria for mortality and fourth for morbidity amongst tropical parasitic diseases (Mathers et al., 2007).

Although the century-old practice of leishmanization, the deliberate infection of naive people with virulent Leishmania major, is defended by some authors for vaccination against tegumentary leishmaniasis (Khamesipour et al., 2006), the development of lesions resistant to treatment makes this practice unrecommendable. Furthermore, while first generation vaccines of whole killed parasite vaccines have been developed and tested against CL and VL their average clinical efficacy was considered to be low (54\%; reviewed in Palatnik-de-Sousa, 2008). Indeed, the only field trial against human VL was performed in Sudan (Khalil et al., 2000), with an autoclaved L. major vaccine with BCG and achieved $43.3 \%$ of vaccine efficacy (VE = incidence in non-vaccinated individuals - incidence in vaccinated individuals/incidence in non-vaccinated individuals $\times 100$ ), only among LST converters, which is impressive considering the high mortality and virulence of kala-azar in that area. The safety of this preparation on children was also assayed (Khalil et al., 2006). These data however are contested by a recent metanalysis (Noazin et al., 2009).

Only a single product (Leish-111f), a fusion protein of three relatively conserved L. major proteins (thiol-specific antioxidant, stress inducible protein 1 , and elongation initiation factor) formulated with MPL-SE is entering phase II clinical testing in humans, including human VL as a therapeutic vaccine (Coler and Reed, 2005; Nascimento et al., 2010) but there is no human vaccine licensed for prophylaxis against VL.

\section{FIELD ASSAYS OF VACCINES AND LICENSED VACCINES FOR CANINE LEISHMANIASIS}

Many Leishmania antigens have been identified as potential vaccine candidates against canine ZVL (reviewed by Palatnik-deSousa, 2008), but very few have been tested in field assays.

The first generation vaccines developed for humans were also tested against canine ZVL. In an initial comparison of vaccine formulations, with no challenge, Lasri et al. (1999) demonstrated that dogs vaccinated with autoclaved L. major promastigote lysate (ALM) and BCG showed an in vitro lymphocyte proliferative response, while dogs immunized with ALM and saponin expressed a main humoral antibody response against L. infantum. Mayrink and co-workers, using a Leishmania braziliensis lysate and BCG vaccine, in a formulation related to the Leishvacin, previously shown to be about $50 \%$ protective against tegumentary leishmaniasis in humans (Antunes et al., 1986), obtained 90\% protection against experimental canine kala-azar in the kennel (Mayrink et al., 1996) but failed to detect any significant difference between vaccines and placebos in a well designed field Phase III assay (Genaro et al., 1996; Table 1). The $90 \%$ protection in the kennel assay was related to the absence of the parasite in bone marrow cultures of 9 of the 10 vaccinated dogs that were challenged with only $10^{6} \mathrm{cul}-$ tured promastigotes of Leishmania chagasi (Mayrink et al., 1996). The difference between the artificial and the natural challenge in this case could account for the failure of the vaccine in the field assay. In Iran, on the other hand the use of Aluminum hydroxide precipitated $L$. major vaccine plus BCG resulted in $69.3 \%$ of vaccine efficacy against the natural infection by L. infantum in Iran (Mohebali et al., 2004; Table 1). The incidence rate was 3.7\% $(6 / 162)$ in vaccinated dogs and $12.0 \%(17 / 141)$ in control dogs.

In the first Phase III trial with a second-generation dog vaccine, Dunan et al., using a L. infantum semi-purified lyophilized protein preparation $(94-67 \mathrm{kDa})$, paradoxically achieved, a significantly higher rate of infection in vaccinated than in control dogs. This vaccine then, while effective in murine models, developed no protection against canine kala-azar in the field (Dunan et al., 1989; Table 1).

Two dog vaccines achieved successful results in Phase III trials: the fucose-mannose ligand (FML)-saponin vaccine (Leishmune $^{\circledR}$; da Silva et al., 2001; Borja-Cabrera et al., 2002, 2010; Palatnik-de-Sousa et al., 2008) composed of the antigen of $L$. donovani promastigotes, named FML (Palatnik et al., 1989) and the QS21 and deacylated saponins of Quillaja saponaria (OliveiraFreitas et al., 2006; Table 1). The FML was antigenic for human (Palatnik-de-Sousa et al., 1995) and dogs (Borja-Cabrera et al., 1999) and Leishmune ${ }^{\circledR}$ was immunogenic, immunoprophylactic, and immunotherapeutic in mice and hamsters and field trials for dogs (Palatnik-de-Sousa et al., 1994; Santos et al., 2002, 2003, 2007; Borja-Cabrera et al., 2004, 2008, 2010). In the first Phase III assay, four obits and six symptomatic cases among 30 surviving placebo treated dogs $(33 \%)$ were detected and confirmed by parasite analysis and PCR. No obits were detected among vaccines and infection was confirmed in 3/36 oligosymptomatic dogs (8.33\%), making $92 \%$ protection, and $76 \%$ vaccine efficacy (da Silva et al., 2001). In the second assay, the infective pressure was higher and 2 years after vaccination, obits were detected in $8 / 33$ (25\%) of the placebo treated and $1 / 20(5 \%)$ of the vaccinated dogs, making $95 \%$ protective effect and $80 \%$ vaccine efficacy. This protection lasted for at least 3.5 years and was concomitant with the reduction of the human incidence of the disease in the area (Borja-Cabrera et al., 2002). Noteworthy, the VE values for the FML-saponin vaccine revealed protection against severe diseases and obits due to canine ZVL (Palatnik-de-Sousa et al., 2008).

The FML-vaccine was considered a second-generation vaccine candidate and participated in the fourth Meeting on SecondGeneration-Leishmania vaccines held in Mérida in May 2001 (Dumonteil et al., 2001). In 2003, the FML-saponin vaccine was licensed for prophylaxis against canine ZVL in Brazil under the name of Leishmune ${ }^{\circledR}$, and has been used in Brazil since 2004 and it obtained its definitive license in October, 2011.

The vaccine was considered safe and was well tolerated (Parra et al., 2007; Table 1). After 2 years of vaccination of a cohort of 550 Leishmune $^{\circledR}$ vaccinated exposed dogs, only $1 \%$ of the animals died of ZVL and $1.2 \%$ were symptomatic. Simultaneously, $39 \%$ of deaths and $20.6 \%$ of symptomatic cases were detected among untreated exposed control animals $(p<0.005$; BorjaCabrera et al., 2008). The Leishmune ${ }^{\circledR}$ vaccine is prophylactic 
Table 1 | Canine vaccines for visceral leishmaniasis assayed in field trials.

\begin{tabular}{|c|c|c|c|c|}
\hline Vaccine & Composition & Licensed* & VE $(\%)^{* *}$ & Results obtained \\
\hline Leishvacin & $\begin{array}{l}\text { L. braziliensis } \\
\text { lysate + BCG }\end{array}$ & - & - & Protective in kennel assay but failed in Phase III assay in Brazil \\
\hline $\begin{array}{l}\text { Lyophilized } \\
\text { protein } \\
\text { preparation }\end{array}$ & $\begin{array}{l}\text { L. infantum } \\
\text { semi-purified } \\
\text { proteins }(94-67 \mathrm{kDa})\end{array}$ & - & - & Protective in mice assays but not in field trial in France \\
\hline Leishmune ${ }^{\circledR}$ & $\begin{array}{l}\text { L. donovani FML } \\
\text { antigen and QS21 } \\
\text { and deacylated } \\
\text { saponins of Quillaja } \\
\text { saponaria }\end{array}$ & + & $76-80$ & $\begin{array}{l}\text { Immunogenic, immunoprophylactic, and immunotherapeutic in mice and hamsters } \\
\text { Long-lasting protection against infection, severe disease, and deaths of ZVL in dog } \\
\text { field trials in Brazil } \\
\text { Safe and well tolerated } \\
\text { Vaccinated dogs do not expose parasites and are negative in xenodiagnosis } \\
\text { The generated dog antibodies block the transmission of the disease by sand flies } \\
\text { With double saponin concentration is therapeutic against naturally or experimentally } \\
\text { acquired ZVL. In immunochemotherapy promotes the sterile cure } \\
\text { Leishmune }{ }^{\circledR} \text { enhances the levels of IFN- } \gamma \text {, NO, and anti- } L \text {. chagasi lgG2, the early and } \\
\text { persistent activation of neutrophils and monocytes } \\
\text { Leishmune }{ }^{\circledR} \text { increases the CD } 8+\text { T-cells expressing IFN- } \gamma \text { and sustain or increases } \\
\text { the proportions of CD4+ and CD21-B lymphocytes } \\
\text { Leishmune }{ }^{\circledR} \text { vaccination does not interfere in epidemiological serological control tests } \\
\text { A decrease in human and canine incidence and in canine seroprevalence of ZVL was } \\
\text { observed after dog vaccination in two Brazilian towns }\end{array}$ \\
\hline LiESAP & $\begin{array}{l}54 \text { kDa excreted } \\
\text { protein of } L \text {. } \\
\text { infantum + MDP }\end{array}$ & - & $92 \%$ & $\begin{array}{l}\text { Long-lasting protection against, infection but not against deaths or severe disease by } \\
\text { ZVL, in a field assay performed in France at a lower infective pressure endemic region } \\
\text { Vaccinated dogs showed a significant leishmanicidal effect of macrophages due to } \\
\text { an IFN- } \gamma \text { dependent activation; a NO-mediated apoptosis of intracellular amastigotes, } \\
\text { a strong and long-lasting cell-mediated immunity revealed by positive IDR, an anti- } \\
\text { leishmanial activity of monocytes, and by the in vitro activities of the anti-LiESAp } \\
\text { antibodies } \\
\text { A similar antigen to LiESAp+QA21 saponin was licensed in Europe in } 2011 \text { with } \\
\text { undisclosed results of field assays }\end{array}$ \\
\hline
\end{tabular}

${ }^{*}$ For prophylaxis against canine visceral leishmaniasis.

${ }^{*} V$ E, vaccine efficacy in Phase III trials.

against canine ZVL VL, protects $98 \%$ of vaccinated dogs (BorjaCabrera et al., 2008), and reduces the parasite burden accessible for transmission back to sand flies, as disclosed by their negative results of PCR for Leishmania DNA in blood and lymph nodes and negative immunohistochemistry reactions in skin (Nogueira et al., 2005). The generated antibodies block the transmission of the disease by sand flies in the field (Saraiva et al., 2006; Palatnik-de-Sousa et al., 2008). Indeed, while sand flies fed upon pre-immune sera showed higher percent of infection and number of parasites/insect, giving a high infection index, sand flies fed upon Leishmune ${ }^{\circledR}$ sera (mainly IgG2 anti-FML antibodies) showed a $74.3 \%$ reduction in infection; (Saraiva et al., 2006). On the other hand, compared to the respective pre-immune fed controls, the sand flies fed on sera of infected animals (IgG1 predominant antibodies) showed, a pronounced enhancement of infection (331.9\%; Palatnik-deSousa et al., 2008). Xenodiagnosis using Lutzomyia longipalpis disclose that $2 / 9$ naturally infected dogs, infected phlebotomies, while 0/19 Leishmune ${ }^{\circledR}$ vaccinated dogs did not. The two infected dogs showing positive xenodiagnosis were the most symptomatic (more than three clinical signs) among the nine tested, while the other seven were asymptomatic or oligosymptomatic (Palatnikde-Sousa et al., 2008; de Amorim et al., 2010). The anti-FML antibody response induced by Leishmune ${ }^{\circledR}$ is mainly of the IgG2 subtype (Mendes et al., 2003). A total of 150,000 healthy dogs were vaccinated in Brazil up to October 2011. We also observed that Leishmune ${ }^{\circledR}$ formulated with double saponin adjuvant concentration has a therapeutic effect against naturally (Borja-Cabrera et al., 2004) or experimentally acquired ZVL (Santos et al., 2007). While immunotherapy with the saponin-enriched Leishmune ${ }^{\circledR}$ reduces the symptomatology, the rate of obits and the parasite load in lymph nodes, immunochemotherapy with Leishmune ${ }^{\circledR}$, Allopurinol, and Amphotericin B promotes the sterile cure, turning to negative the PCR reactions for Leishmania DNA (Borja-Cabrera et al., 2010).

Leishmune ${ }^{\circledR}$ induced an immunological pattern characterized by enhanced levels of IFN- $\gamma, \mathrm{NO}$, and anti- $L$. chagasi IgG2 (Araújo 
et al., 2009), the early and persistent activation of neutrophils and monocytes, and increased the CD8+ T-cells expressing IFN- $\gamma$ (Araújo et al., 2008; Table 1). This increase of CD8+ T-cells is expected for the QS21 saponin adjuvant of Leishmune ${ }^{\circledR}$ (OliveiraFreitas et al., 2006) and it was also described in the immunotherapy assays against naturally (Borja-Cabrera et al., 2004) and experimentally acquired ZVL (Santos et al., 2007). Leishmune ${ }^{\circledR}$ also induced early phenotypic changes in neutrophils (increase in $\mathrm{MHCII}+$ and decrease in CD32+ and CD18+ activation markers) and monocytes, CD8 + T-cell activation, and a selective proinflammatory pattern (IFN- $\gamma / \mathrm{NO}$; Araújo et al., 2011). Other studies also revealed the sustained or increased proportions of CD4+ and CD21-B lymphocytes and the increased proportions of CD8+ T-cells (Borja-Cabrera et al., 2004, 2010; Santos et al., 2007) and the diminished CD4+/CD25+ T-cell counts and increased IFN- $\gamma$ levels in dogs vaccinated with Leishmune ${ }^{\circledR}$ (de Lima et al., 2010). Similar to the situation of human VL patients, the symptomatic disease in dogs is correlated with a "suppressive" pattern of T-cell responses, with a dominant role for IL-10 in ongoing, nonprotective immune responses (Nylen and Sacks, 2007; Carrillo and Moreno, 2009). In view of this similarity between human and canine VL, the fact that Leishmune ${ }^{\circledR}$ has shown promise as a therapeutic vaccine in ZVL is encouraging. The therapeutic efficacy in ZVL of Leish-110f, which induces mainly B-cell and CD4+ T-cell responses, was indistinguishable from the effect of the MPL-SE adjuvants alone (Miret et al., 2008). This may suggest that a therapeutic vaccine against human VL should, akin to canine ZVL, aim to induce both CD4+ and CD8+ T-cells (Kaye and Aebischer, 2011).

Since canine ZVL in Brazil is epidemiologically controlled by serological enquire, and Leishmune ${ }^{\circledR}$ was designed to induce a strong humoral response against the FML antigen, to facilitate the monitoring during field assays, there was a concern that vaccinated dogs could not be differentiated serologically from infected dogs (Marcondes et al., 2011). The predominance of IgG2 antibodies to FML, on the other hand, was proposed to be a tool for differentiation (Mendes et al., 2003). The results obtained from the control campaign disclosed however that there was no reason for concern since in the field, dogs vaccinated with Leishmune ${ }^{\circledR}$ did not become seroreactive in the official test used by the enquire (Palatnik-de-Sousa et al., 2009; Table 1). In the epidemic area of Campo Grande, Brazil, the serological control campaign evaluated 110,000 dogs, 5,860 of which were Leishmune ${ }^{\circledR}$ uninfected vaccines. Only $1.3 \%$ of positivity (76 among 5,860) was detected. These seropositive dogs were seronegative for the L. chagasi HSP recombinant antigen and showed no parasite evidence in bone marrow and lymph nodes (Palatnik-de-Sousa et al., 2009).

A possible additive effect of Leishmune ${ }^{\circledR}$ vaccination over dog culling, on the decrease of the incidence of canine and human ZVL was studied in two Brazilian endemic areas, from 2004 to 2006 (Palatnik-de-Sousa et al., 2009; Table 1). In Araçatuba, a decline of $25 \%$ was seen in the incidence of ZVL in dogs with a $61 \%$ decline in human cases (36-14 cases), indicating the additive effect of Leishmune ${ }^{\circledR}$ vaccination over regular dog culling. In Belo Horizonte, where $8.1 \%(12,113 / 149,470)$ of the dogs were vaccinated up to 2006 , the districts that had had greater vaccine coverage $(85.7 \%$ of the doses) exhibited declined or sustained levels of canine and human cases of ZVL, while those with less vaccine coverage (14.3\% of the doses), showed rising curves of canine and human cases of the disease. In the districts with higher vaccination levels, human cases declined by $36.5 \%$ falling from 2004 to 2006 outside of the $95 \%$ confidence interval (CI95\%) of the less vaccinated districts (CI95\% 2.23-21.11), which showed an average increase of $11.67 \%$. From 1999 to 2006, the increase of canine seroprevalence and of human cases of the disease in all districts were significantly correlated $(p=0.001)$, confirming the importance of the dog as the infectious reservoir of the disease. The decrease in dog culling $(-p=0.007)$ and human incidence $(-p=0.043)$ were significantly correlated with the increase in the number of vaccinated animals, indicating the prophylactic impact of Leishmune ${ }^{\circledR}$ vaccination on the decrease of the proportions of infectious dog and human populations, and so indirectly indicating a decrease in the number of dogs sacrificed (Palatnik-de-Sousa et al., 2009).

The mathematical model for control of leishmaniasis developed by Dye compared the efficacy of various control methods in the reduction of human and canine incidence of the disease (Dye, 1996). According to this model, and regarding the canine incidence, killing infected dogs is the least successful strategy while an effective veterinary drug should perform better, even with the conservative assumption that only infectious dogs are treated. A dog vaccine has higher impact, because it is prophylactic and the insecticide treatment would be the best approach for dogs. The expected outcome of control on human incidence is that killing dogs is again the least successful strategy and that immunizing people is less effective than immunizing dogs because it has no impact on the dynamics of infection in the dog population. The insecticide control would be the most effective strategy.

We used the data of human and canine incidence obtained before and after Leishmune ${ }^{\circledR}$ vaccination in Araçatuba and Belo Horizonte (Palatnik-de-Sousa et al., 2009) in order to see if they are related to what expected according the control model of Dye (1996; Figures 1A,B). The expected efficacy for the vaccine in bringing down the canine incidence of the disease is disclosed by plotting along the $y$ axis the incidence of VL in dogs after vaccination divided by its value before vaccination and expressed as a percentage, and in the $x$ axis the fraction of the susceptible dogs converted to resistant by the vaccine treatment (Dye, 1996). In Araçatuba, Brazil, the VL incidence in dogs after vaccination was $21.77 \%$ (2006) and before vaccination 30.01\% (2003) giving a percent ratio of $72.54 \%$ which corresponds to a transformation of $25 \%$ of the dog population from susceptible to resistant or protected (Palatnik-de-Sousa et al., 2009; Figure 1A). This was achieved vaccinating only $7.531 \%$ of the dog population. In Belo Horizonte, on the other hand, the decline in human incidence was observed after dog vaccination in several districts. In the Nordeste district, human cases declined from 24 to 18 giving a percent ratio of $72 \%$ which corresponds to $28 \%$ of the human population moving to a resistant class (Palatnik-de-Sousa et al., 2009; Figure 1B). This was achieved by vaccinating only $11.03 \%$ of the whole dog population.

The other second-generation vaccine, $L i E S A p$, composed of the $54-\mathrm{kDa}$ excreted protein of L. infantum plus MDP also reached Phase III trials after a kennel assay against $L$. infantum infection (Table 1). Parasites were detected in the bone-marrow of $3 / 3$ 

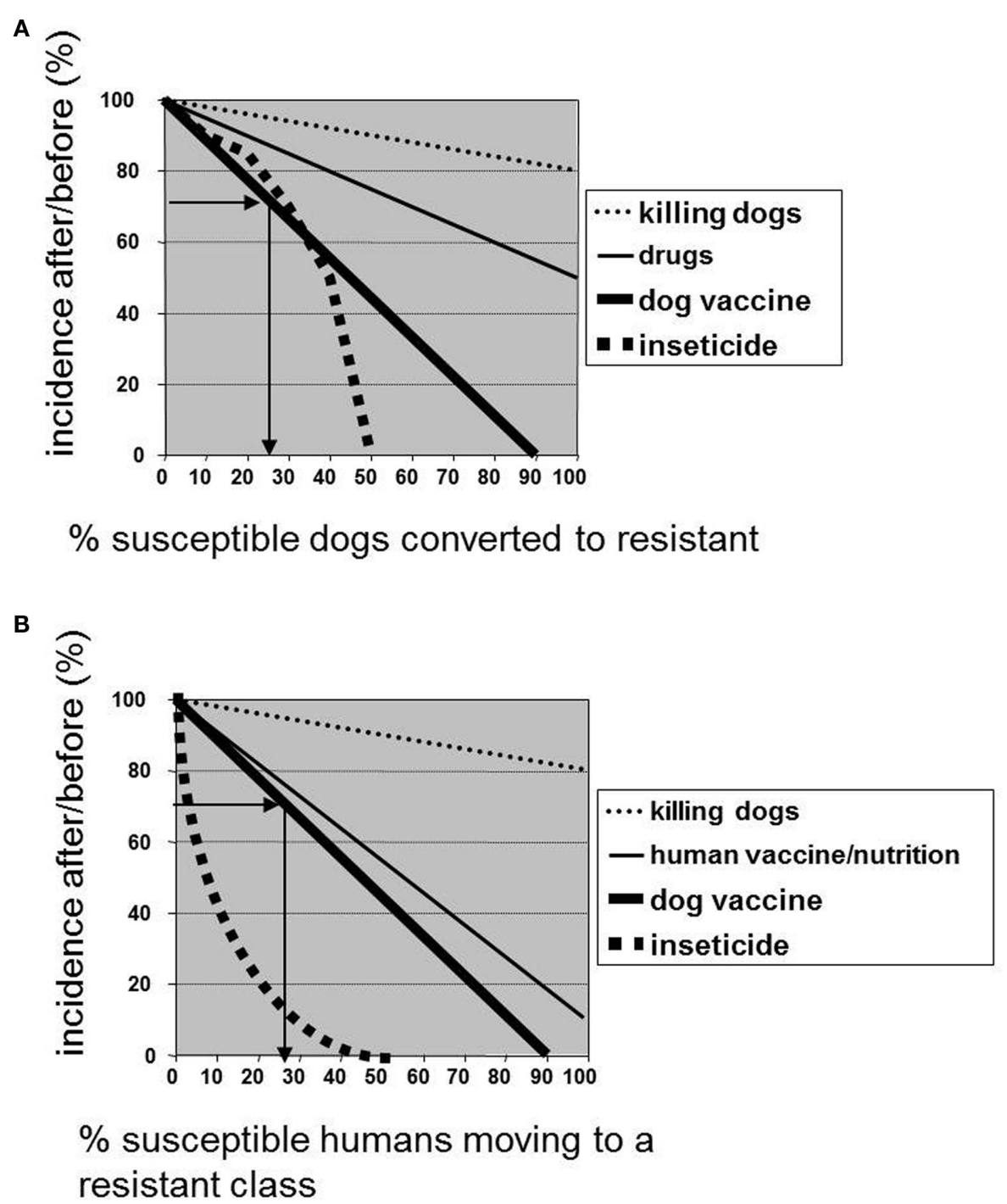

FIGURE 1 | Impact of the use of Leishmune ${ }^{\circledR}$ vaccine on the decrease of dog and human incidence of ZVL in Brazil. The curves show the expected efficacy of different control methods in bringing down the (A) prevalence of infectiousness in dogs, and (B) the incidence of human visceral leishmaniasis according to the model of Dye (1996). The $y$-axes show the stable prevalence (A) or incidence (B) after control, divided by the respective values before control, and expressed as a percentage and the $X$ axes record the percent change promoted by each control method of control moving a fraction of susceptible dogs or people to the resistant class. The arrows show the percent of dog (A)

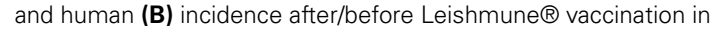
2004-2006 and their respective plot of the percent of dog (A) and human (B) population that became protected and resistant to infection after vaccine treatment. placebo treated controls, while they were absent in 3/3 vaccinated dogs (Lemesre et al., 2005). The double blind random trial further performed with $L i$ ESAp + MDP in naturally exposed dogs of South France revealed that after 2 years, an incidence of infection of $0.61 \%(1 / 165)$ in vaccines versus $6.86 \%(12 / 175)$ in control dogs making a 92\% VE (Lemesre et al., 2007). In any dog showing clinical and/or serological evidence, infection was confirmed by the presence of parasites in bone marrow aspirates cultured in NNN media and also by PCR analysis (Lemesre et al., 2007). Differently from what was described for the FML-saponin vaccine (da Silva et al., 2001; Borja-Cabrera et al., 2002, 2008), the LiESAp vaccine induced protection against infection (Lemesre et al., 2007) but not against severe disease or death by VL. No obits at all, were described in the 2 years LiESAp assay (Lemesre et al., 2007), pointing to the lower infective pressure of the endemic region. The immune response generated in the LiESAp vaccinated dogs was confirmed by the finding of: a significant leishmanicidal effect of macrophages due to an IFN- $\gamma$ dependent activation; a NOmediated apoptosis of intracellular amastigotes (Holzmuller et al., 2005), a strong and long-lasting CMI revealed by positive IDR, an anti-leishmanial activity of monocytes, and by the in vitro activities of the anti-LiESAp antibodies (Bourdoiseau et al., 2009).

In Europe, a formulation related to the LiESAp vaccine was licensed for commercialization under the name of CaniLeish ${ }^{\circledR}$, in 
early 2011 and is currently being launched in Portugal, Spain, France, Greece, and Italy. It is as a second-generation defined peptidic antigen composed of Excreted-Secreted proteins of the supernatant of cultures of L. infantum. Differently from what was published before (Holzmuller et al., 2005; Lemesre et al., 2005, 2007; Bourdoiseau et al., 2009) this formulation does not include MDP but the QA21 adjuvant of Q. saponaria Molina instead (Virbac, 2011; Table 1).

As explained by WHO guidelines (WHO, 1997), confirmation of infection by very sensitive methods such as PCR or culture (Lemesre et al., 2005, 2007) represents a very early end-point of the development of the disease, while kala-azar obits and severe clinical cases (da Silva et al., 2001; Borja-Cabrera et al., 2002) are distant end-points which occur much later in the development of infection. A comparison between efficacies of Leishmune ${ }^{\circledR}$ and LiESAp should only be performed using the same infective pressure and the same end-point targets (WHO, 1997).

Finally, a vaccine called Leish-Tec ${ }^{\circledR}$ was also licensed in Brazil. It is composed of the recombinant A2-antigen of Leishmania amastigotes and is adjuvanted by saponin (Fernandes et al., 2008). While protection due to the Leishmune ${ }^{\circledR}$ vaccine has been extensively investigated in laboratory models (reviewed by Palatnik-deSousa et al., 2008), explained through an immunological approach (Araújo et al., 2008, 2009, 2011), and reported in: control versus trial-field assays with cohorts including 117 (da Silva et al., 2001), 85 (Borja-Cabrera et al., 2002), 72 (Nogueira et al., 2005), and 1138 dogs (Parra et al., 2007; Borja-Cabrera et al., 2008); immunotherapy assays with 66 (Borja-Cabrera et al., 2010) and 24 dogs (Santos et al., 2007); and in 19,392 vaccinated dogs in two Brazilian towns (Palatnik-de-Sousa et al., 2009), there is only one report of an experimental kennel assay with Leish-Tec ${ }^{\circledR}$ which was tested on seven dogs and compared with four untreated controls (Fernandes et al., 2008). There is no information about the infectivity of the strain used for challenge in that study and the lack of deaths in the control animals suggests that the challenge was mild. There are no reports of controlled-trial-field studies with Leish-Tec ${ }^{\circledR}$, but despite the lack of peer-reviewed scientific publications, the vaccine was licensed in Brazil in 2008.

Since it was demonstrated that a canine vaccine promotes a decrease in the human and canine incidence of ZVL (Palatnik-deSousa et al., 2009), an increase in vaccine coverage for dogs, especially in the absence of a licensed human vaccine for leishmaniasis, would certainly bring about an interruption of epidemics.

\section{VACCINES FOR CANINE LEISHMANIASIS UNDER DEVELOPMENT}

The $L$. braziliensis lysate of a first generation vaccine against CL, which failed to show efficacy against canine ZVL when formulated with BCG, is now under research but adjuvanted with saponin (Giunchetti et al., 2007, 2008b). The vaccine increased the anti-Leishmania IgG isotypes, together with higher levels of lymphocytes, particularly circulating CD8(+) T-lymphocytes, and $L$. chagasi antigen-specific CD8(+) T-lymphocytes, as expected for a Q. saponaria saponin containing vaccine (Giunchetti et al., 2007). When combined to sand-fly saliva proteins it revealed an additional increase in circulating CD21+ B-cells, CD5+, and CD4+ T-cells (Giunchetti et al., 2008b).
There is a general consensus stating that the capacity to respond to multiple antigens may be an essential requisite of an efficacious vaccine (Working Group on Research Priorities for Development of Leishmaniasis Vaccines et al., 2011). Multiple antigens are included in a first generation or second-generation complex vaccines such as Leishmune ${ }^{\circledR}$ or LiESAp (Lemesre et al., 2007; Palatnik-de-Sousa et al., 2008) that already showed strong efficacy in field assays. However, from the industrial point of view, obtaining of protozoa vaccines has some limitations. Growing protozoa and extracting native antigens is laborious, expensive, and requires additional bovine products that are forbidden to be used since the emergence of bovine spongiform encephalopathy. On the other hand many subunits of Leishmania antigens have already been described, used alone, or in combination and are even available in the recombinant form (reviewed by Palatnik-de-Sousa et al., 2008; Working Group on Research Priorities for Development of Leishmaniasis Vaccines et al., 2011). These defined vaccines could be used in future multiple recombinant vaccines against canine ZVL.

The most promising candidates seem to be the LACK, LeIF, TSA, LmSTI1, H1, Cpa + CPb, KMP11, and NH36 (reviewed by Palatnik-de-Sousa, 2008). The last approach in second-generation vaccines is the use of recombinant proteins that were tested in kennel assays in a dog model against ZVL (Molano et al., 2003; Fujiwara et al., 2005; Gradoni et al., 2005; Poot et al., 2006; Moreno et al., 2007). None have advanced to Phase III dog trials. The multicomponent Leish-111f fusion protein containing the antigens TSA, LmSTI1, and LeIF, in formulation with MPL-SE or AdjuPrime, was immunogenic in dogs challenged with $L$. chagasi (Fujiwara et al., 2005) and L. infantum (MML; Moreno et al., 2007), but failed to prevent $L$. infantum natural infection, or disease progression in dogs in an open kennel trial (Gradoni et al., 2005). However it was useful as an adjunct therapy together with Glucantime in treating a field population of dogs suffering from ZVL due to L. chagasi infection (Miret et al., 2008). The vaccination was safe and induced a twofold to threefold increase in antigen-specific proliferative response in vitro after cure, but was lacking a clear clinical benefit (though the trial was not powered to reveal small effects; Kaye and Aebischer, 2011). Leish-110f in the form of an experimental vaccine designated MML was also tested alongside recombinant $L$. infantum histone $\mathrm{H} 1$ and hydrophilic acylated protein B1 (HASPB1; Moreno et al., 2007) as prophylactic vaccines against experimental ZVL. Dogs were vaccinated with either MML adjuvanted with MPL-SE or H1 or HASPB1 adjuvanted with Montanide-ISA 720 and subsequently challenged with $10^{8} \mathrm{~L}$. infantum promastigotes. All vaccines were immunogenic, however they developed different boost responses after infection. For example, MML antibody responses were strongly boosted, HASPB1 responses weakly so and $\mathrm{H} 1$ response unaffected by infection (Moreno et al., 2007). Fewer H1 and HASPB1 immunized dogs developed CVL symptoms (37 and 50\%, respectively) compared with control or MML-vaccinated dogs (71 and $75 \%$, respectively), but larger studies would be needed to confirm the efficacy of these vaccines (Palatnik-de-Sousa et al., 2008; Kaye and Aebischer, 2011; Working Group on Research Priorities for Development of Leishmaniasis Vaccines et al., 2011).

Compared to recombinant protein vaccines, DNA vaccines are much more stable and have the advantage of low production costs, 
no need for cold chain distribution, and the flexibility of combining multiple genes in a simple construct. A lot of interest has been generated for the development of a vaccine against leishmaniasis in recent years, with studies going on in the labs on experimental models. LACK, LeIF, TSA, LmSTI1, H1, CpA + CpB, KMP11, and NH36 are the most promising candidates that may find a place in the forthcoming years, since they have already been tested in various animal models (reviewed by Palatnik-de-Sousa, 2008).

Immunization with HPB-LACK protected dogs against ZVL (Ramiro et al., 2003) by increasing the IFN- $\gamma$ and IL-12 expression, lymphocyte proliferative response, and the IgG2 to IgG1 ratio and it led to decreasing clinical symptoms, number of parasites in target tissues, and IL-4 expression. A prime boost vaccination with $\mathrm{CpA}+\mathrm{CpB}$, Montanide 720, and CPG protected dogs against ZVL, as evidenced by the increase in IgG2 specific antibody synthesis, lymphocyte proliferation, IFN $\gamma /$ IL-10 secretion, and DTH response (Rafati et al., 2005). No death or clinical signs were reported, probably due to the very low infective challenge $\left(5 \times 10^{6}\right.$ promastigotes). Eight out of 10 vaccinated dogs were considered protected based on their PCR negative results; however, no significant conclusion could be drawn from the study, because it used only two untreated control dogs (Rafati et al., 2005). A cocktail of plasmid DNA encoding KMPII, TRYP, LACK, and GP63 did not protect dogs against $L$. infantum virulent challenge (Rodríguez-Cortés et al., 2007b).

Recently, a dominant antigen in the FML complex, a nucleoside hydrolase of $36 \mathrm{kDa}$, has been shown in the recombinant form or as a DNA vaccine to reproduce some of the Leishmune ${ }^{\circledR}$ effects in mice (Aguilar-Be et al., 2005). The NH36 DNA vaccine protected mice against infection by L. chagasi, Leishmania mexicana (Aguilar-Be et al., 2005), and Leishmania amazonensis (Souza and Palatnik-de-Sousa, 2009), indicating its potential usefulness in a bivalent immunoprophylactic vaccine for the control of both endemics. Protection by the DNA vaccine was higher

\section{REFERENCES}

Abranches, P., and Silva-Pereira, M. C., Conceição-Silva, F. M., SantanaGomes, G. M., and Janz, J. G. (1991). Canine leishmaniasis: pathological and ecological factors influencing transmission of infection. J. Parasitol. 77, 557-561.

Aguilar-Be, I., Zardo, R. S., Paraguai de Souza, E., Borja-Cabrera, G. P., Rosado-Vallado, M., Mut-Martin, M., Garcia-Miss, M. R., Palatnikde-Sousa, C. B., and Dumonteil, E. (2005). Cross-protective efficacy of a prophylactic Leishmania donovani DNA vaccine against visceral and cutaneous murine leishmaniasis. Infect. Immun. 73, 812-819.

Almeida, M. A. O., Jesus, E. E. V., Sousa-Atta, M. L. B., Alves, L. C., Berne, M. E. A., and Atta, A. M. (2005). Antileishmanial antibody profile in dogs naturally infected with Leishmania chagasi.
Vet. Immunol. Immunopathol. 106, 151-158.

Alvar, J., Aparicio, P., Aseffa, A., Den Boer, M., Canavate, C., Dedet, J. P., Gradoni, L., Ter Horst, R., Lopez-Velez, R., and Moreno, J. (2008). The relationship between leishmaniasis and AIDS: the second 10 years. Clin. Microbiol. Rev. 21, 334-359.

Alvar, J., Cañavate, C., Molina, R., Moreno, J., and Nieto, J. (2004). Canine leishmaniasis. Adv. Parasitol. 57, 1-88.

Alves, C. F., de Amorim, I. F., Moura, E. P., Ribeiro, R. R., Alves, C. F., Michalick, M. S., Kalapothakis, E., BrunaRomero, O., Tafuri, W. L., Teixeira, M. M., and Melo, M. N. (2009). Expression of IFN-gamma, TNFalpha, IL-10 and TGF-beta in lymph nodes associates with parasite load and clinical form of disease in dogs naturally infected with Leishmania

than that induced by the recombinant NH36 or the FML antigen plus saponin, and it is related to IFN- $\gamma$-producing CD4+ T-cells, which are characteristic of a TH1 type immune response (Aguilar-Be et al., 2005). The DNA vaccine showed prophylactic and immunotherapeutic effects against ZVL in a kennel assay (Borja-Cabrera et al., 2009, 2012). The immunotherapy treatment increased survival and reduced clinical status of $L$. chagasi-highly infected dogs through the enhancement of a NH36-specific CD4+ T-cell response (Borja-Cabrera et al., 2012).

The protection induced by the NH36 recombinant vaccine is related to its $\mathrm{C}$-terminal domain bearing the required $\mathrm{T}$-cell epitopes that are responsible for a main $\mathrm{CD} 4+\mathrm{T}$-cell-mediated immune response that has the enhancement of the IDR reaction and the increases in ratios of TNF $\alpha / \mathrm{IL}-10 \mathrm{CD} 4+$ producing cells as strong correlates of protection (Nico et al., 2010). The less defined but nevertheless effective Leishmune ${ }^{\circledR}$ vaccine may therefore become replaced by a synthetic product comprising its active ingredients (Kaye and Aebischer, 2011).

The control of the companion dog population for VL is fundamental in order to avoid the spread of the disease between humans and dogs. A high level of infection in dogs, particularly in impoverished areas, just before the start of the human epidemic, or during the epidemic, or a rising prevalence of canine infection before the epidemic all strongly predicted a high incidence of human VL (Werneck et al., 2007). Recent research demonstrates that the use of insecticides both in residences and in impregnated dog necklaces and/or the use of preventive canine vaccine could potentially substitute the dog culling contributing to the eradication of the disease. In any case, the research on human vaccines and the large use of canine vaccines against VL should be stimulated in order to reduce the incidence of both the canine and human disease.

\section{ACKNOWLEDGMENTS}

The author thanks David Straker for the English language editing of this manuscript.

(Leishmania) chagasi. Vet. Immunol. Immunopathol. 128, 349-358.

Antônio, E. G., Malacco, M. A. F., Gontijo, C. M. F., Moreira, E. F., Caldas, I. S., Pena, J. L., and Machado-Coelho, G. L. L. (2007). Canine visceral leishmaniasis in the Krenak indigenous community, Resplendor, Minas Gerais State, Brazil. Cad. Saúde Pública 27, 603-607.

Antunes, C. M., Mayrink, W., Magalhães, P. A., Costa, A., Melo, M. N., Dias, M., Michalick, M. S. M., Williams, P., Lima, A. O., Vieira, J. B. F., and Schetini, A. P. M. (1986). Controlled field trials of a vaccine against New World cutaneous leishmaniasis. Int. J. Epidemiol. 15, 572-580.

Araújo, M. S., de Andrade, R. A., Sathler-Avelar, R., Magalhães, C. P., Carvalho, A. T., Andrade, M. C., Campolina, S. S., Mello, M. N.,
Vianna, L. R., Mayrink, W., Reis, A. B., Malaquias, L. C., Rocha, L. M., and Martins-Filho, O. A. (2011). Immunological changes in canine peripheral blood leukocytes triggered by immunization with first or second generation vaccines against canine visceral leishmaniasis. Vet. Immunol. Immunopathol. 141, 64-75.

Araújo, M. S., de Andrade, R. A., SathlerAvelar, R., Teixeira-Carvalho, A., Andrade, M. C., Vianna, L. R., Mayrink, W., Reis, A. B., Malaquias, L. C., Mello, M. N., and MartinsFilho, O. A. (2009). T-cell-derived cytokines, nitric oxide production by peripheral blood monocytes and seric anti-Leishmania (Leishmania) chagasi IgG subclass patterns following immunization against canine visceral leishmaniasis using Leishvaccine and Leishmune. Vaccine 27, 1008-1017. 
Araújo, M. S., de Andrade, R. A., Vianna, L. R., Mayrink, W., Reis, A. B., Sathler-Avelar, R., TeixeiraCarvalho, A., Andrade, M. C., Mello, M. N., and Martins-Filho, O. A. (2008). Despite Leishvaccine and Leishmune trigger distinct immune profiles, their ability to activate phagocytes and CD8+ T-cells support their high-quality immunogenic potential against canine visceral leishmaniasis. Vaccine 26, 2211-2224.

Ashford, D. A., Badaró, R., Eulalio, C., Freire, M., Miranda, C., Zalis, M., and David, J. R. (1993). Studies on the control of visceral leishmaniasis: validation of the Falcon assay screening test-enzyme linked immunosorbent assay (Fast-ELISA ${ }^{\mathrm{TM}}$ ) for field diagnosis of canine visceral leishmaniasis. Am. J. Trop. Med. Hyg. 48, 1-8.

Baneth, G., Koutinas, A. F., SolanoGallego, L., Bourdeau, P., and Ferrer, L. (2008). Canine leishmaniasis - new concepts and insights on an expanding zoonosis: part one. Trends Parasitol. 24, 324-330.

Baneth, G., and Shaw, S. E. (2002). Chemotherapy of canine leishmaniasis. Vet. Parasitol. 106, 315-324.

Barbieri, C. L. (2006). Immunology of canine leishmaniasis. Parasite Immunol. 28, 329-337.

Borja-Cabrera, G. P., Correia Pontes, N. N., da Silva, V. O., Paraguai de Souza, E., Santos, W. R., Gomes, E. M., Luz, K. G., Palatnik, M., and Palatnik de Sousa, C. B. (2002). Long lasting protection against canine kala-azar using the FML-QuilA saponin vaccine in an endemic area of Brazil (São Gonçalo do Amarante). Vaccine 20, 3277-3284.

Borja-Cabrera, G. P., Cruz Mendes, A., Paraguai de Souza, E., Okada, L. Y. H., Trivellato, F. A. A., Kawasaki, J. K. A., Costa, A. C., Reis, A. B., Genaro, O., Palatnik, M., and Palatnik de Sousa, C. B. (2004). Effective immunotherapy against canine visceral leishmaniasis with the FMLvaccine. Vaccine 22, 2234-2243.

Borja-Cabrera, G. P., da Silva, V. O., da Costa, R. T., Barbosa Reis, A., Mayrink, W., Genaro, O., and Palatnik-de-Sousa, C. B. (1999). The FML-ELISA assay in diagnosis and prognosis of canine visceral leishmaniasis. Am. J. Trop. Med. Hyg. 61, 296-301.

Borja-Cabrera, G. P., Santos, F. B., Nico, D., Gravino, A. E., Manna, L., Palatnik, M., and Palatnik-de-Sousa, C. B. (2012). The Leishmune ${ }^{\circledR}$ 's Nucleoside hydrolase DNA vaccine as an aid in immunotherapy of canine visceral leishmaniasis. Procedia Vaccinology 1. (in press).

Borja-Cabrera, G. P., Santos, F. B., Picillo, E., Gravino, E., Manna, L., and Palatnil de Sousa, C. B. (2009). Nucleoside hydrolase DNA vaccine against visceral leishmaniasis. Procedia Vaccinol. 1, 104-109.

Borja-Cabrera, G. P., Santos, F. N., Bauer, F. S., Parra, L. E., Menz, I., Morgado, A. A., Soares, I. S., Batista, L. M., and Palatnik-de-Sousa, C. B. (2008). Immunogenicity assay of the Leishmune vaccine against canine visceral leishmaniasis in Brazil. Vaccine 26, 4991-4997.

Borja-Cabrera, G. P., Santos, F. N., Santos, F. B., Trivellato, F. A., Kawasaki, J. K., Costa, A. C., Castro, T., Nogueira, F. S., Moreira, M. A., Luvizotto, M. C., Palatnik, M., and Palatnik-de-Sousa, C. B. (2010). Immunotherapy with the saponin enriched-Leishmune vaccine versus immunochemotherapy in dogs with natural canine visceral leishmaniasis. Vaccine 28, 597-603.

Bourdoiseau, G., Bonnefont, C., Hoareau, E., Boehringer, C., Stolle, T., and Chabanne, L. (1997). Specific IgG1 and IgG2 antibody and lymphocyte subset levels in naturally Leishmania infantuminfected treated and untreated dogs. Vet. Immunol. Immunopathol. 59, 21-30.

Bourdoiseau, G., Hugnet, C., Gonçalves, R. B., Vézilier, F., Petit-Didier, E., and Papierok, G., and Lemesre, J. L. (2009). Effective humoral and cellular immunoprotective responses in Li ESAp-MDP vaccinated protected dogs. Vet. Immunol. Immunopathol. 128, 71-78.

Braga, M. D., Coelho, I. C. B., Lima Pompeu, M., Evans, T. G., Tavares, M. I., Teixeira, M. J., and Oliveira Lima, J. W. (1998). Controle do calazar canino: comparação dos resultados de um programa de eliminação rápida de cães sororreagentes por ensaio imuno-enzimático com outro de eliminação tardia de cães sororreagentes por teste de imunofluorescência indireta de eluato de papel filtro. Rev. Soc. Bras. Med. Trop. $31,419-424$.

Cardoso, L., Schallig, H. D., Neto, F., Kroon, N., and Rodrigues, M. (2004). Serological surveyof Leishmania infection in dogs from the municipality of Peso da Regua (Alto Douro, Portugal) using the direct agglutination test (DAT) and fast agglutination screening test (FAST). Acta Trop. 91, 95-100.

Carrillo, E., and Moreno, J. (2009). Cytokine profiles in canine visceral leishmaniasis. Vet. Immunol. Immunopathol. 128, 67-70.

Chabalgoity, J. A., Moreno, M., Carol, H., Dougan, G., and Hormaeche, C. E. (2001). Salmonella typhimurium as a basis for a live oral Echinococcus granulosus vaccine. Vaccine 19, 460-469.

Chamizo, C., Moreno, J., and Alvar, J. (2005). Semi-quantitative analysis of cytokine expression in asymptomatic canine leishmaniasis. Vet. Immunol. Immunopathol. 103 67-75.

Chappuis, F., Sundar, S., Hailu, A., Ghalib, H., Rijal, S., Peeling, R. W., Alvar, J., and Boelaert, M. (2007). Visceral leishmaniasis: what are the needs for diagnosis, treatment and control? Nat. Rev. Microbiol. 5, 873-882.

Coler, R. N., and Reed, S. G. (2005), Second-generation vaccines against leishmaniasis. Trends Parasitol. 21, 244-249.

Corrêa, A. P., Dossi, A. C., de Oliveira Vasconcelos, R., Munari, D. P., and de Lima, V. M. (2007). Evaluation of transformation growth factor betal, interleukin-10, and interferon-gamma in male symptomatic and asymptomatic dogs naturally infected by Leishmania (Leishmania) chagasi. Vet. Parasitol. 143, 267-274.

Costa, C. H., Tapety, C. M., and Werneck, G. L. (2007). Control of visceral leishmaniasis in urban areas: randomized factorial intervention trial. Rev. Soc. Bras. Med. Trop. 40, 415-419.

Courtenay, O., Quinnell, R. J., Garcez, L. M., Shaw, J. J., and Dye, C. (2002). Infectiousness in a Cohort of Brazilian dogs: why culling fails to control visceral leishmaniasis in areas of high transmission. J. Inf. Dis. 186, 1314-1320.

da Silva, V. O., Borja-Cabrera, G. P. Correia Pontes, N. N., Paraguai de Souza, E., Luz, K. G., Palatnik, M. and Palatnik de Sousa, C. B. (2001). A phase III trial of efficacy of the FML-vaccine against canine kalaazar in an endemic area of Brazil (São Gonçalo do Amarante, RN). Vaccine 19, 1068-1081.

Day, M. J. (2007). Immunoglobulin G subclass distribution in canine leishmaniasis: a review and analysis of pitfalls in interpretation. Vet. Parasitol. 147, 2-8.

Day, M. J. (2011). The immunopathology of canine vector-borne diseases. Parasit. Vectors 4, 49.

de Amorim, I. F., Freitas, E., Alves, C. F., Tafuri, W. L., Melo, M. N., Michalick, M. S., and da Costa-Val,
A. P. (2010). Humoral immunological profile and parasitological statuses of Leishmune vaccinated and visceral leishmaniasis infected dogs from an endemic area. Vet. Parasitol. $173,55-63$

de Lima, V. M., Ikeda, F. A., Rossi, C. N., Feitosa, M. M., Vasconcelos, R. O., Nunes, C. M., and Goto, H. (2010). Diminished CD4+/CD25+ $\mathrm{T}$ cell and increased IFN-gamma levels occur in dogs vaccinated with Leishmune in an endemic area for visceral leishmaniasis. Vet. Immunol. Immunopathol. 135, 296-302.

de Oliveira, S. S., and de Araújo, T. M. (2003). Evaluation of control measures for visceral leishmaniasis (kala azar) in an endemic area in Bahia, Brazil (1995-2000). Cad. Saúde Publica 19, 1681-1690.

De Souza, V. M. M., Julião, F. S., Neves, R. C. S., Magalhães, P. B., Bisinotto, T. V., Lima, A. S., de Oliveira, S. S., and Júnior, E. D. M. (2008). Communitary assay for assessment of effectiveness of strategies for prevention and control of human visceral leishmaniasis in the municipality of Feira de Santana, State of Bahia, Brazil. Epidemiol. Serv. Saúde 17, 97-106.

Deplazes, P., Smith, N. C., Arnold, P., Lutz, H., and Eckert, J. (1995). Specific IgG1 and IgG2 antibody responses of dogs to Leishmania infantum and other parasites. Parasite Immunol. 17, 451-458.

Dietze, R., Barros, G. B., Teixeira, L., Harris, J., Michelson, K., Falqueto, A., and Corey, R. (1997). Effect of eliminating seropositive canines on the transmission of visceral leishmaniasis in Brazil. Clin. Infect. Dis. 25, 1240-1242.

Dumonteil, E., McMahon-Pratt, D., and Price, V. L. (2001). "Report of the fourth TDR/IDRI meeting on second generation vaccines against Leishmaniasis," in UNDP/World Bank/WHO Special Programme for Research \& Training in Tropical Diseases (TDR). ed. TDR/WHO (Geneva). Available at: http://www.who.int/leishmaniasis/ resources/documents/en/TDR_PRD _LEISH_VAC_01.1.pdf

Dunan, S., Frommel, D., Monjour, L., Ogunkolade, B. W., and Cruz, A, and Quilici, M. (1989). The Phocean veterinary study group on visceral leishmaniasis. Vaccination trial against canine visceral leishmaniasis. Parasite Immunol. 11, 397-402.

Duprey, Z., Steurer, F., Rooney, J., Kirchhoff, L., Jackson, J., Rowton, E., and Schantz, P. (2006). Canine visceral leishmaniasis, United States 
and Canada, 2000-2003. Emerging Infect. Dis. 12, 440-446.

Dye, C. (1996). The logic of visceral leishmaniasis control. Am. J. Trop. Med. Hyg. 55, 125-130.

Evans, K. J., and Kedzierski, L. (2012). Development of vaccines against visceral Leishmaniasis. J. Trop. Med. doi:10.1155/2012/892817

Fernandes, A. P., Costa, M. M., Coelho, E. A., Michalick, M. S., de Freitas, E., Melo, M. N., Tafuri, W. L., Resende Dde, M., Hermont, V., Abrantes Cde, F., and Gazzinelli, R. T. (2008). Protective immunity against challenge with Leishmania (Leishmania) chagasi in beagle dogs vaccinated with recombinant A2 protein. Vaccine 26, 5888-5895.

Fernandez-Perez, F. J., Gomez-Munoz, M. T., Mendez, S., and Alunda, J. M. (2003). Leishmania-specific lymphoproliferative responses and IgG1/IgG2 immunodetection patterns by Western blot in asymptomatic, symptomatic and treated dogs. Acta Trop. 86, 83-91.

Ferroglio, E., Poggi, M., and Trisciuoglio, A. (2008). Evaluation of $65 \%$ permethrin spot-on and deltamethrin-impregnated collars for canine Leishmania infantum infection prevention. Zoonoses Public Health 55, 145-148.

França-Silva, J. C., Costa, R. T., Siqueira, A. M., Machado-Coelho, G. L. L., Costa, C. A., Mayrink, W., Vieira, E. P., Costa, J. S., Genaro, O., and Nascimento, E. (2003). Epidemiology of canine visceral leishmaniasis in the endemic area of Montes Claros Municipality, Minas Gerais State, Brazil. Vet. Parasitol. 111, 161-173.

Fujiwara, R. T., Vale, A. M., Franca da Silva, J. C., da Costa, R. T., Quetz Jda, S., Martins Filho, O. A., Reis, A. B., Correa Oliveira, R., Machado-Coelho, G. L., Bueno, L. L., Bethony, J. M., Frank, G., Nascimento, E., Genaro, O., Mayrink, W., Reed, S., and Campos-Neto, A. (2005). Immunogenicity in dogs of three recombinant antigens (TSA, LeIF and LmSTI1) potential vaccine candidates for canine visceral leishmaniasis. Vet. Res. 36, 827-838.

Genaro, O., Pinto, J. A., Da Costa, C. A., França-Silva, J. C., Costa, R. T., Silva, J. C., Sanguinetti, L. S. R., Vieira, E. P., and Toledo, V. P. C. P. Mayrink, W. (1996). Phase III randomized double blind clinical trial on the efficacy of a vaccine against canine visceral leishmaniasis in urban area of Montes Claros, MG, Brazil. Mem. Inst. Osw. Cruz. 91, 116.

Giffoni, J. H., de Almeida, C. E., dos Santos, S. O., Ortega, V. S., and de
Barros, A. T. (2002). Evaluation of $65 \%$ permethrin spot-on for prevention of canine visceral leishmaniasis: effect on disease prevalence and the vectors (Diptera: Psychodidae) in a hyperendemic area. Vet. Ther. 3, 485-492.

Giunchetti, R. C., Corrêa-Oliveira, R., Martins-Filho, O. A., TeixeiraCarvalho, A., Roatt, B. M., de Oliveira Aguiar-Soares, R. D., de Souza, J. V., das Dores Moreira, N., Malaquias, L. C., Mota e Castro, L. L., de Lana, M., and Reis, A. B. (2007). Immunogenicity of a killed Leishmania vaccine with saponin adjuvant in dogs. Vaccine 25, 7674-7686.

Giunchetti, R. C., Martins-Filho, O. A., Carneiro, C. M., Mayrink, W., Marques, M. J., Tafuri, W. L., Correa-Oliveira, R., and Reis, A. B. (2008a). Histopathology, parasite density and cell phenotypes of the popliteal lymph node in canine visceral leishmaniasis. Vet. Immunol. Immunopathol. 121, 23-33.

Giunchetti, R. C., Corrêa-Oliveira, R., Martins-Filho, O. A., TeixeiraCarvalho, A., Roatt, B. M., de Oliveira Aguiar-Soares, R. D., Coura-Vital, W., de Abreu, R. T., Malaquias, L. C., Gontijo, N. F., Brodskyn, C., de Oliveira, C. I., Costa, D. J., de Lana, M., and Reis, A. B. (2008b). A killed Leishmania vaccine with sand fly saliva extract and saponin adjuvant displays immunogenicity in dogs. Vaccine 26, 623-638.

Gradoni, L., Foglia Manzillo, V., Pagano, A., Piantedosi, D., De Luna, R., Gramiccia, M., Scalone, A., Di Muccio, T., and Oliva, G. (2005). Failure of a multi-subunit recombinant leishmanial vaccine (MML) to protect dogs from Leishmania infantum infection and to prevent disease progression in infected. Vaccine 23, 5245-5251.

Guarga, J. L., Moreno, J., Lucientes, J., Gracia, M. J., Peribanez, M. A., Alvar, J., and Castillo, J. A. (2000). Canine leishmaniasis transmission: higher infectivity among naturally infected dogs to sandflies is associated with lower proportions of $\mathrm{T}$ helper cells. Res. Vet. Sci. 69, 249-253.

Guarga, J. L., Moreno, J., Lucientes, J., Gracia, M. J., Peribáñez, M. A., and Castillo, J. A. (2002). Evaluation of a specific immunochemotherapy for the treatment of canine visceral leishmaniasis. Vet. Immunol. Immunopathol. 88, 13-20.

Harhay, M. O., Olliaro, P. L., Costa, D. L., and Costa, C. H. (2011). Urban parasitology: visceral leishmaniasis in Brazil. Trends Parasitol. 27, 403-409.
Holzmuller, P., Cavaleyra, M., Moreaux, J., Kovacic, R., Vincendeau, P., Papierok, G., and Lemesre, J. L. (2005). Lymphocytes of dogs immunised with purified excretedsecreted antigens of Leishmania infantum co-incubated with Leishmania infected macrophages produce IFN gamma resulting in nitric oxide-mediated amastigote apoptosis. Vet. Immunol. Immunopathol. 106, 247-257.

Iniesta, L., Gállego, M., and Portús, M. (2005). Immunoglobulin G and $\mathrm{E}$ responses in various stages of canine leishmaniasis. Vet. Immunol. Immunopathol. 103, 77-81.

Jerónimo, S. M., Teixeira, M. J., Sousa, A. D., Thielking, P., Pearson, R. D., and Evans, T. G. (2000). Natural history of Leishmania (Leishmania) chagasi infection in Northeastern Brazil: long-term follow-up. Clin. Infect. Dis. 30, 608-609.

Kaye, P. M., and Aebischer, T. (2011). Visceral leishmaniasis: immunology and prospects for a vaccine. Clin. Microbiol. Infect. 17, 1462-1470.

Keenan, C. M., Hendricks, L. D., Lightner, L., Webster, H. K., and Johnson, A. J. (1984). Visceral leishmaniasis in the German shepherd dog. I. Infection, clinical disease, and clinical pathology. Vet. Pathol. 21, 74-79.

Khalil, E. A., El Hassan, A. M., Zijlstra, E. E., Mukhtar, M. M., Ghalib, H. W., Musa, B., Ibrahim, M. E., Kamil, A. A., Elsheikh, M., Babiker, A., and Modabber, F. (2000). Autoclaved Leishmania major vaccine for prevention of visceral leishmaniasis: a randomised, double-blind, BCGcontrolled trial in Sudan. Lancet 356 , 1565-1569.

Khalil, E. A., Musa, A. M., Modabber, F., and El-Hassan, A. M. (2006). Safety and immunogenicity of a candidate vaccine for visceral leishmaniasis (Alum-precipitated autoclaved Leishmania major + BCG) in children: an extended phase II study. Ann. Trop. Paediatr. 26, 357-361.

Khamesipour, A., Rafati, S., Davoudi, N., Maboudi, F., and Modabber, F. (2006). Leishmaniasis vaccine candidates for development: a global overview. Indian J. Med. Res. 123, 423-438.

Killick-Kendrick, R., Killick-Kendrick, M., Focheux, C., Dereure, J., Puech, M. P., and Cadiergues, M. C. (1997). Protection of dogs from the bites of phlebotomine sandflies by deltamethrin collars for the control of canine leishmaniasis. Med. Vet. Entomol. 11, 105-111.

Koutinas, A. F., Scott, D. W., Kantos, V., and Lekkas, S. (1993). Skin lesions in canine leishmaniasis (kala-azar): a clinical and histopathological study on 22 spontaneous cases in Greece. Vet. Dermatol. 3, 121-131.

Lage, R. S., Oliveira, G. C., Busek, S. U., Guerra, L. L., Giunchetti, R. C., Corrêa-Oliveira, R., and Reis, A. B. (2007). Analysis of the cytokine profile in spleen cells from dogs naturally infected by Leishmania chagasi. Vet. Immunol. Immunopathol. 115, 135-145.

Lanotte, G., Rioux, J. A., Croset, H., and Vollhardt, Y. (1975). Ecologie des leishmanioses dans le Sud de la France. VIII Complement a lápplication épidemiologique de la technique dímmunofluorescence: les titres geometrices et aritmetiques moyens dans la leishmaniose canine. Ann. Parasitol. Hum. Comp. 50, 1-5. Lasri, S., Sahibi, H., Sadak, A., Jaffe, C. L., and Rhalem, A. (1999). Immune responses in vaccinated dogs with autoclaved Leishmania major promastigotes. Vet. Res. 30, 441-449.

Lemesre, J. L., Holzmuller, P., Cavaleyra, M., Gonçalves, R. B., Hottin, G., and Papierok, G. (2005). Protection against experimental visceral leishmaniasis infection in dogs immunized with purified excreted secreted antigens of Leishmania infantum promastigotes. Vaccine 23 , 2825-2840.

Lemesre, J. L., Holzmuller, P., Gonçalves, R. B., Bourdoiseau, G., Hugnet, C., Cavaleyra, M., and Papierok, G. (2007). Long-lasting protection against canine visceral leishmaniasis using the LiESAp-MDP vaccine in endemic areas of France: doubleblind randomised efficacy field trial. Vaccine 25, 4223-4234.

Ma, J., Bulger, P. A., Dante, S., Davis, D. R., Perilli-Palmer, B., and Coughlin, R. T. (1995). Characterization of canine humoral immune responses to outer surface protein subunit vaccines and to natural infection by Lyme disease spirochetes. J. Infect. Dis. 171, 909-915.

Magalhães, P. A., Mayrink, W., Costa, C. A., Melo, M. N., Dias, M., Batista, S. M., Michalick, M. S. M. and Williams, P. (1980). Calazar na zona do Rio Doce-Minas Gerais. Resultados de medidas profiláticas. Rev. Inst. Med. Trop. Sao Paulo 22, 197-202.

Maguill, A. J. (1995). Epidemiology of the leishmaniases. Dermatol. Clin. 13, 505-523.

Maia, C., and Campino, L. (2008). Methods for diagnosis of canine leishmaniasis and immune response to infection. Vet. Parasitol. 158, 274-287. 
Maia, C., and Campino, L. (2011). Can domestic cats be considered reservoir hosts of zoonotic leishmaniasis? Trends Parasitol. 27, 341-344.

Manna, L., Reale, S., Picillo, E., Vitale, F., and Gravino, A. E. (2008). Interferon-gamma (INFgamma), IL4 expression levels and Leishmania DNA load as prognostic markers for monitoring response to treatment of leishmaniotic dogs with miltefosine and allopurinol. Cytokine 44, 288-292.

Marcondes, M., Ikeda, F. A., Vieira, R. F., Day, M. J., Lima, V. M., Rossi, C. N., Perri, S. H., and Biondo, A. W. (2011). Temporal IgG subclasses response in dogs following vaccination against Leishmania with Leishmune ${ }^{\circledR}$. Vet. Parasitol. 181, 153-159.

Maroli, M., Mizzon, V., Siragusa, C., D'Oorazi, A., and Gradoni, L. (2001). Evidence for an impact on the incidence of canine leishmaniasis by the use of deltamethrinimpregnated dog collars in southern Italy. Med. Vet. Entomol. 15, 358-363.

Mathers, C. D., Ezzati, M., and Lopez, A. D. (2007). Measuring the burden of neglected tropical diseases: the global burden of disease framework. PLoS Negl. Trop. Dis. 1, e114. doi:10.1371/journal.pntd.0000114.

Mayrink, W., Genaro, O., Silva, J. C., da Costa, R. T., Tafuri, W. L., Toledo, V. P., da Silva, A. R., Reis, A. B., Williams, P., and da Costa, P. W. (1996). Phase I and II open clinical trials of a vaccine against Leishmania chagasi infections in dogs. Mem. Inst. Oswaldo Cruz 91, 695-697.

Mendes, C. O., Paraguai de Souza, E., Borja-Cabrera, G. P., Melo Batista, L. M., Santos, M. A., Parra, L. E., Menz, I., and Palatnik de Sousa, C. B. (2003). IgG1/IgG2 antibody dichotomy in sera of vaccinated or naturally infected dogs with visceral leishmaniasis. Vaccine 21, 2589-2597.

Ministério da Saúde. Secretaria de Vigilância em Saúde Departamento de Vigilância Epidemiológica. (2006). Manual de Vigilância e Controle da Leishmaniose Visceral Brasília - DF, a edição 3. ${ }^{a}$ reimpressão Série A. Available at: http://www.portal.saude.gov.br/por tal/arquivos/pdf/manual_leish_visc eral2006.pdf

Miret, J., Nascimento, E., Sampaio, W., França, J. C., Fujiwara, R. T., Vale, A., Dias, E. S., Vieira, E., da Costa, R. T., Mayrink, W., Campos Neto, A., and Reed, S. (2008). Evaluation of an immunochemotherapeutic protocol constituted of $N$-methyl meglumine antimoniate
(Glucantime) and the recombinant Leish-110f+MPL-SE vaccine to treat canine visceral leishmaniasis. Vaccine 26, 1585-1594.

Miró, G., Gálvez, R., Mateo, M., Montoya, A., and Descalzo, M. A., Molina, R. (2007). Evaluation of the efficacy of a topically administered combination of imidacloprid and permethrin against Phlebotomus perniciosus in dog. Vet. Parasitol. 143, 375-379.

Mohebali, M., Khamesipour, A., Mobedi, I., Zarei, Z., and Fesharki, R. H. (2004). Double-blind randomized efficacy field trial of alum precipitated autoclaved Leishmania major vaccine mixed with BCG against canine visceral leishmaniasis in Meshkin-Shahr district, I.R. Iran. Vaccine 22, 4097-4100.

Molano, I., Alonso, M. G., Miron, C., Redondo, E., Requena, J. M., Soto, M., Nieto, C. G., and Alonso, C. (2003). A Leishmania infantum multi-component antigenic protein mixed with live BCG confers protection to dogs experimentally infected with L. infantum. Vet. Immunol. Immunopathol. 92, 1-13.

Moreira, E. D. Jr, Mendes de Souza, V. M., Sreenivasan, M., Nascimento, E. G., and Pontes de Carvalho, L. (2004). Assessment of an optimized dog-culling program in the dynamics of canine Leishmania transmission. Vet. Parasitol. 6, 245-252.

Moreno, J., Nieto, J., Chamizo, C., Gonzalez, F., Blanco, F., Barker, F., Barker, D. C., and Alvar, J. (1999). The immune response and PBMC subsets in canine visceral leishmaniasis before and after chemotherapy. Vet. Immunol. Immunopathol. 30, 181-195.

Moreno, J., Nieto, J., Masina, S., Cañavate, C., Cruz, I., Chicharro, C., Carrillo, E., Napp, S., Reymond, C., Kaye, P. M., Smith, D. F., Fasel, N., and Alvar, J. (2007). Immunization with H1, HASPB1 and MML Leishmania proteins in a vaccine trial against experimental canine leishmaniasis. Vaccine 25, 5290-5300.

Mouta-Confort, E., López, J. A., and Mendonça-Lima, F. W. (2010). Seroprevalence and risk factors for canine visceral leishmaniasis in the endemic area of Dias D'Ávila, State of Bahia, Brazil. Rev. Soc. Bras. Med. Trop. 43, 400-404.

Nascimento, E., Fernandes, D. F., Vieira, E. P., Campos-Neto, A., Ashman, J. A., Alves, F. P., Coler, R. N., Bogatzki, L. Y., Kahn, S. J., Beckmann, A. M., Pine, S. O., Cowgill, K. D., Reed, S. G., and Piazza, F. M. (2010). A clinical trial to evaluate the safety and immunogenicity of the
LEISH-F1+MPL-SE vaccine when used in combination with meglumine antimoniate for the treatment of cutaneous leishmaniasis. Vaccine 28, 6581-6587.

Nico, D., Claser, C., Borja-Cabrera, G. P., Travassos, L. R., Palatnik, M., Soares, I. S., Rodrigues, M. M., and Palatnikde-Sousa, C. B. (2010). Adaptive immunity against Leishmania nucleoside hydrolase maps its c-terminal domain as the target of the CD4+ $\mathrm{T}$ cell-driven protective response. PLoS Negl. Trop. Dis. 4, e866. doi:10.1371/journal.pntd.0000866

Nieto, C. G., Garcia Alonso, M., Requena, J. M., Miron, C., Soto, M., Alonso, C., and Navarrete, I. (1999). Analysis of the humoral response against total and recombinant antigens of Leishmania infantum: correlation with disease progression in canine experimental leishmaniasis. Vet. Immunol. Immunopathol. 67, 117-130.

Noazin, S., Khamesipour, A., Moulton, L. H., Tanner, M., Nasseri, K., Modabber, F., Sharifi, I., Khalil, E. A., Bernal, I. D., Antunes, C. M., and Smith, P. G. (2009). Efficacy of killed whole-parasite vaccines in the prevention of leishmaniasis: a metaanalysis. Vaccine 27, 4747-4753.

Nogueira, F. S., Moreira, M. A. B., Borja Cabrera, G. P., Santos, F. N., Menz, I., Parra, L. E., Xu, Z., and Chu, H. J. (2005). Palatnik-deSousa CB, Luvizotto MCR. Leishmune ${ }^{\circledR}$ vaccine blocks the transmission of canine visceral leishmaniasis. Absence of Leishmania parasites in blood, skin and lymph nodes of vaccinated exposed dogs. Vaccine 23 , 4805-4810.

Nunes, C. M., Pires, M. M., da Silva, K. M., Assis, F. D., Gonçalves Filho, J., and Perri, S. H. (2010). Relationship between dog culling and incidence of human visceral leishmaniasis in an endemic area. Vet. Parasitol. 170, 131-133.

Nylen, S., and Sacks, D. (2007) Interleukin-10 and the pathogenesis of human visceral leishmaniasis. Trends Immunol. 28, 378-384.

Oliva, G., Scalone, A., Foglia Manzillo, V., Gramiccia, M., Pagano, A., Di Muccio, T., and Gradoni, L. (2006). Incidence and time course of Leishmania infantum infections examined by parasitological, serologic, and nested-PCR techniques in a cohort of naive dogs exposed to three consecutive transmission seasons. J. Clin. Microbiol. 44, 1318-1322.

Oliveira-Freitas, E., Casas, C. P., BorjaCabrera, G. P., Santos, F. N., Nico,
D., Souza, L. O. P., Tinoco, L. W., da Silva, B. P., Palatnik, M., Parente, J. P., and Palatnik-de-Sousa, C. B. (2006). Acylated and deacylated saponins of Quillaja saponaria mixture as adjuvants for the FML-vaccine against visceral leishmaniasis. Vaccine 24, 3909-3920.

Palatnik, C. B., Borojevic, R., Previato, J. O., and Mendonça-Previato, L. (1989). Inhibition of Leishmania donovani promastigote internalization into murine macrophages by chemically defined parasite glycoconjugate. Infect. Immun. 57, 754-763.

Palatnik-de-Sousa, C. B. (2008). Vaccines for leishmaniasis in the fore coming 25 years. Vaccine 26, 1709-1724.

Palatnik-de-Sousa, C. B., Barbosa Ade, F., Oliveira, S. M., Nico, D., Bernardo, R. R., Santos, W. R., Rodrigues, M. M., Soares, I., and Borja-Cabrera, G. P. (2008). FML vaccine against canine visceral leishmaniasis: from second-generation to synthetic vaccine. Expert Rev. Vaccines 7, 833-851.

Palatnik-de-Sousa, C. B., and Day, M. J. (2011). One health: the global challenge of epidemic and endemic leishmaniasis. Parasit. Vectors 4, 197-207.

Palatnik-de-Sousa, C. B., Gomes, E. M., Paraguai de Souza, E., Luz, K., Palatnik, M., and Borojevic, R. (1995). Leishmania donovani: titration of antibodies to the Fucose Mannose Ligand as an aid in diagnosis and prognosis of visceral leishmaniasis. Trans. R. Soc. Trop. Med. Hyg. 89, 390-393.

Palatnik-de-Sousa, C. B., Melo, L. M. B., Borja-Cabrera, G. P., Palatnik, M., and Lavor, C. C. (2004). Improving methods for epidemiological control of canine visceral leishmaniasis based on a mathematical model. Impact on the incidence of the canine and human disease. An. Acad. Bras. Cienc. 76, 583-593.

Palatnik-de-Sousa, C. B., Paraguay de Sousa, E., Gomes, E. M., and Borojevic, R. (1994). The FML vaccine (fucose-mannose ligand) protects hamsters from experimental kala-azar. Braz. J. Assoc. Adv. Sci. Cienc. Cult. 46, 290-296.

Palatnik-de-Sousa, C. B., Santos, W. R., França-Silva, J. C., da Costa, R. T., Reis, A. B., Palatnik, M., Mayrink, W., and Genaro, O. (2001). Impact of canine control on the epidemiology of canine and human visceral leishmaniasis in Brazil. Am. J. Trop. Med. Hyg. 65, 510-517.

Palatnik-de-Sousa, C. B., Silva-Antunes, I., Morgado, A. A., Menz, I., Palatnik, 
M., and Lavor, C. (2009). Decrease of the incidence of human and canine visceral leishmaniasis after dog vaccination with Leishmune ${ }^{\circledR}$ in Brazilian endemic areas. Vaccine 27, 3505-3512.

Papadogiannakis, E. I., Koutinas, A. F., Saridomichelakis, M. N., Vlemmas, J., Lekkas, S., Karameris, A., and Fytianou, A. (2005). Cellular immunophenotyping of exfoliative dermatitis in canine leishmaniasis (Leishmania infantum). Vet. Immunol. Immunopathol. 104, 227-237.

Paranhos-Silva, M., Nascimento, E. G., Melro, M. C., Oliveira, G. G., dos Santos, W. L., Pontes-de-Carvalho, L. C., and Oliveira-dos-Santos, A. J. (1998). Cohort study on canine emigration and Leishmania infection in an endemic area for American visceral leishmaniasis. Implications for the disease control. Acta Trop. 69, 75-83.

Parra, L. E., Borja-Cabrera, G. P., Santos, F. N., Souza, L. O. P., Palatnikde-Sousa, C. B., and Menz, I. (2007). Safety trial using the Leishmune ${ }^{\circledR}$ vaccine against canine visceral leishmaniasis in Brazil. Vaccine 25, 2180-2186.

Pinelli, E., Killick-Kendrick, R., Wagenaar, J., Bernadina, W., del Real, G., and Ruitenberg, J. (1994). Cellular and humoral immune responses in dogs experimentally and naturally infected with Leishmania infantum. Infect. Immun. 62, 229-235.

Pinelli, E., van der Kaaij, S. Y., Slappendel, R., Fragio, C., Ruitenberg, E. J., Bernadina, W., and Rutten, V. P. (1999). Detection of canine cytokine gene expression by reverse transcription-polymerase chain reaction. Vet. Immunol. Immunopathol. 69, 121-126.

Poot, T., Spreeuwenberg, K., Sanderson, S. J., Schijns, V. E. C. J., Mottram, J. C., Coombs, G. H., and Vermeulen, A. N. (2006). Vaccination with a preparation based on recombinant cystein pepetidases and canine IL-12 does not protect dogs from infection with Leishmania infantum. Vaccine 24, 2460-2468.

Pozio, E., Gradoni, L., Bettini, S., and Gramicia, M. (1981). Leishmaniasis in Tuscany (Italy): VI Canine leishmaniasis in the focus of Monte Argentario (Grosseto). Acta Trop. 38, 383-393.

Quinnell, R. J., and Courtenay, O. (2009). Transmission, reservoir hosts and control of zoonotic visceral leishmaniasis. Parasitology 136, 1915-1934.
Quinnell, R. J., Courtenay, O., Garcez, L., and Dye, C. (1997). The epidemiology of canine leishmaniasis: transmission rates estimated from a cohort study in Amazonian Brazil. Parasitology 115, 143-156.

Quinnell, R. J., Courtenay, O., Shaw, M. A., Day, M. J., Garcez, L. M., Dye, C., and Kaye, P. M. (2001). Tissue cytokine responses in canine visceral leishmaniasis. J. Infect. Dis. 183, 1421-1424.

Quinnell, R. J., Kennedy, L. J., Barnes, A., Courtenay, O., Dye, C., Garcez, L. M., Shaw, M. A., Carter, S. D., Thomson, W., and Ollier, W. E. (2003). Susceptibility to visceral leishmaniasis in the domestic dog is associated with MHC class II polymorphism. Immunogenetics 55, 23-28.

Rafati, S., Nakhaee, A., Taheri, T., Taslimi, Y., Darabi, H., Eravani, D., Sanos, S., Kaye, P., Taghikhani, M., Jamshidi, S., and Rad, M. A. (2005). Protective vaccination against canine visceral leishmaniasis using a combination of DNA and protein immunization with cysteine proteinases type I and type II of $L$. infantum. Vaccine 23, 3716-3725.

Ramiro, M. J., Zárate, J. J., Hanke, T., Rodriguez, D., Rodriguez, J. R., Esteban, M., Lucientes, J., Castillo, J. Á., and Larraga, V. (2003). Protection in dogs against visceral leishmaniasis caused by Leishmania infantum is achieved by immunization with a heterologous prime-boost regime using DNA vaccine and vaccinia recombinant vectors expressing LACK. Vaccine 21, 2474-2484.

Ranque, J. M., Quilici, M., and Dunan, S. (1977). "Les leishmanioses de la region provencale. Considerations epidemiologiques et ecologiques," in Colloques Internationaux $d u$ CNRS. Ecologie des leishmanioses, Vol. 239 (Paris: Centre National de la Recherche Scientifique), 285-293.

Reis, A. B., Giunchetti, R. C., Carrillo, E., Martins-Filho, O. A., and Moreno, J. (2010). Immunity to Leishmania and the rational search for vaccines against canine leishmaniasis. Trends Parasitol. 26, 341-349.

Reis, A. B., Teixeira-Carvalho, A., Giuchetti, R. C., Guerra, L. L., Carvalho, M. G., Mayrink, W., Genaro, O., Côrrea-Oliveira, R., and MartinsFilho, O. A. (2006a). Phenotypic features of circulating leucocytes as immunological markers for clinical status and bone marrow parasite density in dogs naturally infected by Leishmania chagasi. Clin. Exp. Immunol. 146, 303-311.

Reis, A. B., Teixeira-Carvalho, A., Vale, A. M., Marques, M. J., Giunchetti,
R. C., Mayrink, W., Guerra, L. L., Andrade, R. A., Corrêa-Oliveira, R. and Martins-Filho, O. A. (2006b). Isotype patterns of immunoglobulins: hallmarks for clinical status and tissue parasite density in Brazilian dogs naturally infected by Leishmania (Leishmania) chagasi. Vet. Immunol. Immunopathol. 112, 102-116.

Reithinger, R., Coleman, P. G., Alexander, B., Vieira, E. P., Assis, G., and Davies, C. R. (2004). Are insecticideimpregnated dog collars a feasible alternative to dog culling as a strategy for controlling canine visceral leishmaniasis in Brazil? Int. J. Parasitol. 34, 55-62.

Rodríguez-Cortés, A., Ojeda, A., LópezFuertes, L., Timón, M., Altet, L., Solano-Gallego, L., Sánchez-Robert, E., Francino, O., and Alberola, J. (2007a). A long term experimental study of canine visceral leishmaniasis. Int. J. Parasitol. 37, 683-693.

Rodríguez-Cortés, A., Ojeda, A., LópezFuertes, L., Timón, M., Atlet, L., Solano-Gallego, L., Sánchez-Robert, E., Francino, O., and Alberola, J. (2007b). Vaccination with plasmid DNA encoding KMP11, TRYP, LACK, and GP63 does not protect dogs against Leishmania infantum experimental challenge. Vaccine 25, 7962-7971.

Romero, G. A., and Boelaert, M. (2010). Control of visceral leishmaniasis in Latin America-a systematic review. PLoS Negl. Trop. Dis. 4, e584. doi:10.1371/journal.pntd.0000584

Sanchez-Robert, E., Altet, L., Alberola J., Rodriguez-Cortés, A., Ojeda, A., López-Fuertes, L., Timon, M., Sanchez, A., and Francino, O. (2008). Longitudinal analysis of cytokine gene expression and parasite load in PBMC in Leishmania infantum experimentally infected dogs. Vet. Immunol. Immunopathol. 125, 168-175.

Santana, D. M., Borja-Cabrera, G. P., Paraguai de Souza, E., Sturm, N. R. Palatnik de Sousa, C. B., and Campbell, D. A. (2002). Nucleoside hydrolase from Leishmania (L.) donovani is an antigen diagnostic for visceral leishmaniasis. Mol. Biochem. Parasitol. 120, 315-319.

Santos, F. N., Borja-Cabrera, G. P., Miyashiro, L. M., Grechi, J., Reis, A. B., Moreira, M. A., Martins Filho, O. A., Luvizotto, M. C., Menz, I., Pessoa, L. M., Goncalves, P. R., Palatnik, M., and Palatnik-deSousa, C. B. (2007). Immunotherapy against experimental canine visceral leishmaniasis with the saponin
enriched-Leishmune vaccine. Vaccine 25, 6176-6190.

Santos, W. R., Aguiar, I. A., Paraguai de Souza, E., de Lima, V. F. M., Palatnik, M., and Palatnik-de-Sousa, C. B. (2003). Immunotherapy against murine experimental visceral leishmaniasis with the FML-vaccine. Vaccine 21, 4668-4676.

Santos, W. R., de Lima, V. M. F., Paraguai de Souza, E., Bernardo, R. R., Palatnik, M., and Palatnik de Sousa, C. B. (2002). Saponins, IL12 and BCG adjuvant in the FML-vaccine formulation against murine visceral leishmaniasis. Vaccine 21, 30-43.

Santos-Gomes, G. M., Rosa, R., Leandro, C., Cortes, S., Romão, P., and Silveira, H. (2002). Cytokine expression during the outcome of canine experimental infection by Leishmania infantum. Vet. Immunol. Immunopathol. 88, 21-30.

Saraiva, E. M., Mendes-Aguiar, C. O., Paraguai de Souza, E., BorjaCabrera, G. P., Fampa, P., Parra, L. E., Menz, I., Galvão Dias, J. Jr., Oliveira, S. M., and Palatnik de Sousa, C. B. (2006). The FML-vaccine (Leishmune $^{\circledast}$ ) against canine visceral leishmaniasis: a transmission blocking vaccine. Vaccine 24, 2423-2431.

Saridomichelakis, M. N. (2009). Advances in the pathogenesis of canine leishmaniasis: epidemiologic and diagnostic implications. Vet. Dermatol. 20, 471-489.

Sideris, V., Karagouni, E., Papadopoulou, G., Garifallou, A., and Dotsika, E. (1996). Canine visceral leishmaniasis in the greater Athens area, Greece. Parasite 3, 125-130.

Solano-Gallego, L., Koutinas, A., Miró, G., Cardoso, L., Pennisi, M. G., Ferrer, L., Bourdeau, P., Oliva, G., and Baneth, G. (2009). Directions for the diagnosis, clinical staging, treatment and prevention of canine leishmaniasis. Vet. Parasitol. 165, 1-18.

Solano-Gallego, L., Llull, J., Ramos, G., Riera, C., Arboix, M., Alberola, J., and Ferrer, L. (2000). The Ibizan hound presents a predominantly cellular immune response against natural Leishmania infection. Vet. Parasitol. 90, 37-45.

Solano-Gallego, L., Miró, G., Koutinas, A., Cardoso, L., Pennisi, M. G., Ferrer, L., Bourdeau, P., Oliva, G., and Baneth, G. (2011). The LeishVet Group. LeishVet guidelines for the practical management of canine leishmaniasis. Parasit. Vectors $20,86$.

Solano-Gallego, L., Riera, C., Roura, X., Inieste, L., Gallego, M., Valladares, J. 
E., Fisa, R., Castillejo, A. S., Alberola, J., Ferrer, L., Arboix, M., and Portus, M. (2001). Leishmania infantum-specific IgG, IgG1 and IgG2 antibody responses in healthy and ill dogs from endemic areas. Evolution in the course of infection and after treatment. Vet. Parasitol. 96, 265-276.

Souza, L. O. P., and Palatnikde-Sousa, C. B. (2009). The Nucleoside hydrolase DNA vaccine VR1012NH36 in prophylactic vaccination against mice tegumentary leishmaniasis. Proc. Vaccinol. 1, 120-123.

Strauss-Ayali, D., Baneth, G., and Jaffe, C. L. (2007). Splenic immune responses during canine visceral leishmaniasis. Vet. Res. 38, 547-564.

Tesh, R. B. (1995). Control of zoonotic visceral leishmaniasis: is it time to change strategies? Am. J. Trop. Med. Hyg. 52, 287-292.

Thomas, C., Roques, M., and Franc, M. (2008). The effectiveness of a pyriprole $(125 \mathrm{mg} / \mathrm{ml})$ and a metaflumizone $(150 \mathrm{mg} / \mathrm{ml})$ combined with amitraz $(150 \mathrm{mg} / \mathrm{ml})$ spot-on treatment in preventing Phlebotomus perniciosus from feeding on dogs. Parasite 15, 93-96.

Travi, B. L., Osorio, E. Y., Saldarriaga, O. A., Cadena, H., Tabares, C. J., Peniche, A., Lee, S., and Melby, P. C. (2009). Clinical, parasitologic, and immunologic evolution in dogs experimentally infected with sand fly-derived Leishmania chagasi promastigotes. Am. J. Trop. Med. Hyg. 81, 994-1003.
Travi, B. L., Tabares, C. J., Cadena, H., Ferro, C., andOsorio, Y (2001). Canine visceral leishmaniasis in Colombia: relationship between clinical and parasitologic status and infectivity for sand flies. Am. J. Trop. Med. Hyg. 64, 119-124.

Vercammen, F., Fernandez-Perez, F. J., del Amo, C., and Alunda, J. M. (2002). Follow-up of Leishmania infantum naturally infected dogs treated with allopurinol: immunofluorescence antibody test, ELISA and Western blot. Acta. Trop. 84, 175-181.

Vides, J. P., Schwardt, T. F., Sobrinho, L. S., Marinho, M., Laurenti, M. D., Biondo, A. W., Leutenegger, C., and Marcondes, M. (2011). Leishmania chagasi infection in cats with dermatologic lesions from an endemic area of visceral leishmaniasis in Brazil. Vet. Parasitol. 178, 22-28.

Virbac. (2011). CaniLeish (R): a primeira vacina na Europa contra a leishmaniose. Available at: http://www.pt.scribd.com/doc/ 56634570/Canileish-revista [accessed February 2011].

Vouldoukis, I., Drapier, J. C., Nüssler, A. K., Tselentis, Y., Da Silva, O. A., Gentilini, M., Mossalayi, D. M., Monjour, L., and Dugas, B. (1996). Canine visceral leishmaniasis: successful chemotherapy induces macrophage antileishmanial activity via the L-arginine nitric oxide pathway. Antimicrob. Agents Chemother. 40, 253-256.
Wang, J. Y., Gao, C. H., Yang, Y. T., Chen, H. T., Zhu, X. H., Lv, S. Chen, S. B., Tong, S. X., Steinmann, P., Ziegelbauer, K., and Zhou, X. N. (2010). An outbreak of the desert sub-type of zoonotic visceral leishmaniasis in Jiashi, Xinjiang Uygur Autonomous Region, People's Republic of China. Parasitol. Int. 59, 331-337.

Werneck, G. L., Costa, C. H., Walker, A. M., David, J. R., Wand, M., and Maguire, J. H. (2007). Multilevel modelling of the incidence of visceral leishmaniasis in Teresina, Brazil. Epidemiol. Infect. 135, 195-201.

Witt, C. J., Richards, A. L., Masuoka, P. M., Foley, D. H., Buczak, A. L., Musila, L. A., Richardson, J. H. Colacicco-Mayhugh, M. G., Rueda, L. M., Klein, T. A., Anyamba, A., Small, J., Pavlin, J. A., Fukuda, M. M., Gaydos, J., Russell, K. L. and AFHSC-GEIS Predictive Surveillance Writing Group. (2009). The AFHSC-Division of GEIS Operations Predictive Surveillance Program: a multidisciplinary approach for the early detection and response to disease outbreaks. BMC Public Health 11(Suppl. 2), S10. doi:10.1186/1471-2458-11S2-S10

Working Group on Research Priorities for Development of Leishmaniasis Vaccines, Costa, C. H., Peters, N. C., Maruyama, S. R., de Brito, E. C. Jr., and Santos, I. K. (2011). Vaccines for the leishmaniasis: proposals for a research agenda. PLoS Negl.
Trop. Dis. 29, e943. doi:10.1371/journal.pntd.0000943

World Health Organisation. (1997). Guidelines for the Evaluation of Plasmodium falciparum Vaccines in Populations Exposed to Natural Infections. Geneva: World Health Organization.

World Heath Organization. (2011). World Health Organization: Leishmaniasis: Background Information. Available at: http://www.who.int/leishmaniasis/en/ [accessed February 2011].

Conflict of Interest Statement: The author declares that the research was conducted in the absence of any commercial or financial relationships that could be construed as a potential conflict of interest.

Received: 06 December 2011; accepted: 20 March 2012; published online: 17 April 2012.

Citation: Palatnik-de-Sousa CB (2012) Vaccines for canine leishmaniasis. Front. Immun. 3:69. doi: 10.3389/fimmu.2012.00069

This article was submitted to Frontiers in Microbial Immunology, a specialty of Frontiers in Immunology.

Copyright (c) 2012 Palatnik-de-Sousa. This is an open-access article distributed under the terms of the Creative Commons Attribution Non Commercial License, which permits non-commercial use, distribution, and reproduction in other forums, provided the original authors and source are credited. 